\title{
Tracking the origins and diet of an endemic island canid (Urocyon littoralis) across 7300
} years of human cultural and environmental change

Courtney A. Hofman ${ }^{123^{*}}$, Torben C. Rick ${ }^{2}$, Jesús E. Maldonado ${ }^{3,4}$, Paul W. Collins ${ }^{5}$, Jon M. Erlandson $^{6}$, Robert C. Fleischer ${ }^{3}$, Chelsea Smith ${ }^{7}$, T. Scott Sillett ${ }^{8}$, Katherine Ralls $^{3}$, Wendy Teeter ${ }^{9}$, René L. Vellanoweth ${ }^{10}$, Seth D. Newsome ${ }^{11}$

${ }^{1}$ Department of Anthropology, University of Oklahoma, Norman, Oklahoma, United States of America

${ }^{2}$ Program in Human Ecology and Archaeobiology, Department of Anthropology, National Museum of Natural History, Smithsonian Institution, Washington, District of Columbia, United States of America

${ }^{3}$ Center for Conservation and Evolutionary Genetics, Smithsonian Conservation Biology Institute, National Zoological Park, Washington, District of Columbia, United States

${ }^{4}$ Department of Vertebrate Zoology, National Museum of Natural History, Smithsonian Institution, Washington, District of Columbia, United States of America

${ }^{5}$ Department of Vertebrate Zoology, Santa Barbara Museum of Natural History, Santa Barbara, California, United States of America

${ }^{6}$ Museum of Natural and Cultural History and Department of Anthropology, University of Oregon, Eugene, OR, United States of America

${ }^{7}$ Department of Anthropology, University of California-Davis, Davis, California, United States of America

${ }^{8}$ Migratory Bird Center, Smithsonian Conservation Biology Institute, National Zoological Park, Washington, District of Columbia, United States of America

${ }^{9}$ Fowler Museum, University of California- Los Angeles, Los Angeles, California, United States of America

${ }^{10}$ Department of Anthropology, California State University, Los Angeles. Los Angeles, California, United States of America

${ }^{11}$ Department of Biology, University of New Mexico, Albuquerque, New Mexico, United States of America

* Corresponding author email: courtney.hofman@ ou.edu (CAH) 
Abstract Ecology; California Channel Islands

Understanding how human activities have influenced the foraging ecology of wildlife is important as our planet faces ongoing and impending habitat and climatic change. We review the canine surrogacy approach (CSA) - a tool for comparing human, dog, and other canid diets in the past - and apply CSA to investigate possible ancient human resource provisioning in an endangered canid, the California Channel Islands fox (Urocyon littoralis). We conducted stable isotope analysis of bone collagen samples from ancient and modern island foxes $(n=214)$ and mainland gray foxes (Urocyon cinereoargenteus, $n=24$ ). We compare these data to isotope values of ancient humans and dogs, and synthesize 29 Accelerator Mass Spectrometry (AMS) radiocarbon dates that fine-tune the chronology of island foxes. AMS dates confirm that island foxes likely arrived during the early Holocene (>7300 cal BP) on the northern islands in the archipelago and during the middle Holocene ( $>5500 \mathrm{cal} \mathrm{BP}$ ) on the southern islands. We found no evidence that island foxes were consistently using anthropogenic resources (e.g., food obtained by scavenging or direct provisioning by Native Americans), except for a few individuals on San Nicolas Island and possibly on San Clemente and Santa Rosa islands. Decreases in $U$. littoralis carbon and nitrogen isotope values between prehistoric times and the $19^{\text {th }}$ century on San Nicolas Island suggest that changes in human land use from Native American hunter-gatherer occupations to historical ranching had a strong influence on fox diet. Island foxes exhibit considerable dietary variation through time and between islands and have adapted to a wide variety of climatic and cultural changes over the last 7300 years. This generalist foraging strategy suggests that endemic island foxes may be more resilient to future

70 changes in resource availability. 
1. Introduction

Humans have had profound effects on past and present wildlife population demography, genetic diversity, and biogeography (Boivin et al., 2016; Erlandson et al., 2014; Grayson, 2001; Hofman et al., 2015a; Lorenzen et al., 2011; Rick and Erlandson, 2008; Storey et al., 2013; Zeder, 2015). A growing body of evidence demonstrates that people have also influenced the foraging ecology of ancient and modern wild animals (Auman et al., 2011; Bentzen et al., 2014;

81 Kristan et al., 2004; Merkle et al., 2011; Newsome et al., 2010, 2015b; Wiley et al., 2013). The

82 diets of wild animals can be altered through intentional (direct feeding) or unintentional

83 (scavenging of human refuse) provisioning by humans (Auman et al., 2011; Merkle et al., 2011;

84 Newsome et al., 2010) or due to anthropogenic changes to ecosystems and resource availability

85 (e.g., landscape clearing and burning, plant and animal introductions) (Wiley et al., 2013).

86 Human provisioning of animals is an important step in the domestication process (Axelsson et

87 al., 2013; Barton et al., 2009; Hu et al., 2008; Makarewicz and Tuross, 2012; Zeder, 2006; Zeder

88 et al., 2006) and dietary changes have also been identified in captive and ritually sacrificed

89 animals held by prehistoric peoples (Sugiyama et al., 2015; White et al., 2001). Unintentional or

90 intentional human provisioning of wild animals can impact body condition (Heiss et al., 2009)

91 and the ability of an animal to effectively teach their young how to forage for wild food. Data

92 sets that track dietary changes over long-term timescales (centuries, millennia) are therefore

93 valuable for identifying anthropogenic impacts. Stable isotope analysis provides a powerful tool

94 for understanding food-web structure (Tieszen and Boutton, 1989) and, along with other data,

95 can provide insights into past and present human-wildlife interactions (Beard and Johnson, 2000;

96 Guiry, 2012; Newsome et al., 2015, 2010; Wiley et al., 2013). 
To examine temporal changes in foraging patterns and explore the utility of stable

98 isotopes in evaluating the impact of potential human provisioning of wildlife, we focus on the

99 chronology and isotope ecology of the island fox (Urocyon littoralis), a range-restricted species

100 of management concern. The island fox, closely related to the mainland gray fox (Urocyon

101 cinereoargenteus)(Hofman et al. 2015b), is endemic to six of California's eight Channel Islands

102 (Figure 1). Several Accelerator Mass Spectrometry (AMS) radiocarbon $\left({ }^{14} \mathrm{C}\right)$ dates suggest that

103 the island fox may be a relatively recent (early to middle Holocene) arrival to the islands. The

104 oldest published island fox remains on the islands are found in archaeological sites and date to

105 7100 years ago (Hofman et al., 2015b; Rick et al., 2009; Vellanoweth, 1998), long after humans

106 first colonized the islands at $\sim 13,000$ cal BP (Erlandson et al., 2011). Recent analysis of

107 mitochondrial genomes also supports an early to mid-Holocene introduction (Hofman et al.,

108 2015b). The origin of foxes on the Channel Islands is uncertain, with hypotheses ranging from a

109 human introduction, to a natural rafting event, or to a combination of the two. Most researchers

110 agree, however, that Native Americans introduced island foxes from the northern to the southern

111 island group >5000 years ago (Aguilar et al., 2004; Collins, 1993, 1991a, 1991b; Hofman et al.,

112 2015b; Johnson, 1975; Orr, 1968; Rick et al., 2009; Vellanoweth, 1998; Wayne et al., 1991).

113 Evidence of resource provisioning by humans could lend support to a human introduction and

114 suggest greater interactions between humans and foxes, which possibly includes semi-

115 domestication, which we define as captive wild animals whose breeding may have been

116 influenced by humans.

117 Here we review and analyze human-fox relationships on California's Channel Islands by

118 examining carbon $\left(\delta^{13} \mathrm{C}\right)$ and nitrogen $\left(\delta^{15} \mathrm{~N}\right)$ isotope values in bone collagen from

119 paleontological, archaeological, historic, and modern island foxes. To place these data in 
120 chronological context, we also synthesize 29 new $(n=21)$ and previously $(n=8)$ reported AMS

$121{ }^{14} \mathrm{C}$ dates measured directly from archaeological and sub-fossil island foxes. Together these data

122 are used to address three interrelated research questions: 1) When and how did foxes arrive on

123 the Channel Islands? 2) Do island fox diets vary through time and between islands? 3) Were

124 island fox diets affected by changes in human occupation and land use patterns through time?

125 2. Background and context

1262.1 Stable isotopes and the Canine Surrogacy Approach

127 To investigate changes in the diet of island foxes, we adopt the "Canine Surrogacy

128 Approach" (CSA) that has been used to investigate human provisioning of dogs in the

129 archaeological record as well as human diets (Cannon et al., 1999; Guiry, 2012; Rick et al.,

130 2011; Tankersley and Koster, 2009; West and France, 2015). CSA asserts that dogs can serve as

131 a proxy for human diet because dogs consume similar foods as their human handlers via

132 handouts and scavenging (Guiry, 2012). Although dogs are generally good proxies for humans,

133 animal age needs to be considered when sampling from the archaeological record (Guiry, 2012).

134 Isotope values from dog bone collagen reflect shorter periods of time than values from humans,

135 due to differences in body size and related differences in collagen isotopic incorporation rates

136 (Guiry, 2012; Pearce et al., 2007). Weaning can also affect isotope values as pups and juveniles

137 have higher $\delta^{15} \mathrm{~N}$ values than adult females because mother's produce milk from proteins and

138 lipids sourced from their own tissues (Fuller et al., 2006; Jenkins et al., 2001; Newsome et al.,

139 2006). After accounting for age effects, we can expand the CSA with human or dog isotope data

140 to test for human provisioning of wild animals.

141 Rick et al. (2011) analyzed a small sample $(n=3)$ of late Holocene island foxes recovered 142 from an archaeological site on Santa Rosa Island (CA-SRI-2) and found that foxes had lower 
$143 \delta^{13} \mathrm{C}$ and $\delta^{15} \mathrm{~N}$ values in comparison to humans and dogs from the same site that had consumed a

144 marine-based diet. Primary production on the California Channel Islands is dominated by plants

145 that use the $\mathrm{C}_{3}$ photosynthetic pathway, low $\delta^{13} \mathrm{C}$ and $\delta^{15} \mathrm{~N}$ values in foxes are indicative of a

146 terrestrial-based diet consisting of rodents, insects, and plants, prey items similar to those

147 consumed by modern island foxes (Cypher et al., 2014). While these samples suggest continuity

148 between the diet of late Holocene and modern foxes on Santa Rosa Island, the sample size from

149 Santa Rosa is small and questions remain about whether these samples fully represent variability

150 in island fox diet across space and through time.

151 Here we expand on these preliminary data and evaluate the hypothesis that humans

152 provisioned island foxes, using a large dataset $(n=214)$ of island foxes spanning 7300 years and

153 seven islands. We define provisioning as the intentional feeding of foxes by humans, including

154 the potential scavenging of anthropogenic foods, because both mechanisms imply human

155 involvement and would yield similar isotope values in foxes. We compare isotope values

156 between humans, dogs, and island foxes to test if humans and island foxes had commensal or

157 mutually beneficial relationships. If humans and foxes had a commensal relationship following

158 the arrival of foxes on the islands, we expect similar isotope values between species, supporting

159 the hypothesis that humans introduced foxes to the Channel Islands.

160 Alternatively, if foxes were scavenging marine carrion, including pinniped carcasses, we

161 also expect they would have higher $\delta^{13} \mathrm{C}$ and $\delta^{15} \mathrm{~N}$ values similar to those of ancient humans and

162 dogs on the Channel Islands that consumed a marine-based diet (Rick et al., 2011). However,

163 occasional scavenging of marine resources might not be detected by analyzing the isotopic

164 composition of bone collagen. This is because bone collagen has a relatively slow isotopic

165 incorporation rate and represents diet integrated over the last several years prior to death, 
166 depending on the size of the animal (Hobson and Clark, 1992; Tieszen et al., 1983). Thus, fox

167 bone collagen that has high $\delta^{13} \mathrm{C}$ and $\delta^{15} \mathrm{~N}$ values is likely the result of the consistent

168 consumption of marine resources, a phenomenon that has not been documented in modern island

169 fox populations (Cypher et al., 2014). Distinguishing between human resource provisioning and

170 scavenging of marine carrion is difficult; therefore we considered foxes that had isotope values

171 within the standard ellipse area of human populations from the Channel Islands to be evidence of

172 human provisioning.

173 Island foxes may have been valued by humans for their fur and their role in managing

174 island rodent populations (Rick et al., 2009). Domestic cats did not arrive in North America until

175 European colonization (Wastlhuber, 1991). If pest control were a factor in fox dispersal, we

176 would expect an island fox diet consistent with terrestrial foods. Ultimately, comparisons of

177 stable isotope bone collagen data from modern foxes to archaeological human, fox, and dog

178 remains can help us explore human resource provisioning and long-term trends in island fox diet

179 within the CSA framework.

$180 \quad 2.2$ The California Channel Islands and island foxes: What do we know?

181 The California Channel Islands, an eight-island archipelago 20 to $100 \mathrm{~km}$ off the

182 southern California coast, have never been connected to the mainland during the Quaternary.

183 However, the northern islands (San Miguel, Santa Rosa, Santa Cruz and Anacapa) composed a

184 single landmass (Santarosae) in the Pleistocene. Santarosae began to separate into what would

185 become the four northern Channel Islands around 11,000 cal BP, with the islands completely

186 separated by 9000 cal BP (Figure 1) (Muhs et al., 2014, 2012; Reeder-Myers et al., 2015;

187 Wenner and Johnson, 1980). Although the southern islands were larger in terms of landmass 
188 when sea levels were lower, they were not connected to each other or to the mainland (Reeder-

189 Myers et al., 2015).

The paleogeography of the islands has shaped their biodiversity (Johnson, 1983, 1980,

191 1975; Wenner and Johnson, 1980). Channel Island terrestrial mammal populations are unevenly

192 distributed among islands and less diverse than the mainland, with only six extant endemic

193 mammals (excluding bats): the island fox, western harvest mouse (Reithrodontomy megalotis),

194 Catalina ground squirrel (Otospermophilus beecheyi nesioticus), the island spotted skunk

195 (Spilogale gracilis amphiala), the deer mouse (Peromyscus maniculatus), and the ornate shrew

196 (Sorex ornatus) (Rick, 2013). Native Americans also introduced dogs to many of the islands

197 during the middle Holocene or earlier (Rick et al., 2008) and a number of non-native and

198 invasive species arrived or were introduced to the islands within the last 200 years after Spanish

199 colonization of California.

200 From ancient hunter-gatherers to historic ranchers, island landscapes have changed

201 significantly since people first arrived on the islands 13,000 years ago (Rick et al., 2014). During

202 the warmer, drier transition at the terminal Pleistocene, island vegetation shifted from a

203 landscape dominated by temperate forest to shrubland-grasslands. By 11,000 cal BP, coastal sage

204 shrub dominated the landscape. Evidence from pollen and charcoal on Santa Rosa Island

205 suggests that by 6900 years ago grassland and perennial herbs predominated, with evidence of

206 wetland plants suggesting that the region became wetter around 4500 years ago (Anderson et al.,

207 2010; Rick et al., 2014). Fire frequency also increased around 9150 years ago and again 3500

208 years ago (Anderson et al., 2010) with the latter thought to be from burning by Native

209 Americans. During the ranching era (mid 1800s-late 1900s), introduced livestock transformed

210 the landscape due to vegetation stripping from overgrazing, soil compaction, and increased 
211 erosion from trampling of the native grassland, which resulted in vegetation changes and large-

212 scale erosion (Erlandson et al., 2005; Johnson, 1980; Rick et al., 2014). Most of the livestock and

213 introduced game species have recently been removed from the islands and vegetation

214 communities are recovering (Corry and McEachern, 2009; McEachern et al., 2015).

215 As one of the few terrestrial mammals on the Channel Islands, the island fox is an apex

216 predator and currently of considerable conservation concern, especially on San Nicolas, where

217 populations have extremely low genetic diversity (Funk et al., 2016; Robinson et al., 2016) and

218 population sizes declined by 25\% between 2013 and 2014 (Coonan, 2015). In the 1990s, fox

219 numbers dropped rapidly due to the introduction of distemper by domestic dogs on Santa

220 Catalina (Coonan et al., 2010) and by golden eagle predation on the northern Channel Islands

221 (Roemer et al., 2002). Through a captive breeding and re-release program, however, fox

222 populations have recovered dramatically on the northern islands (Coonan et al., 2010, 2014).

223 Contemporary island foxes are opportunistic omnivores with diets that vary both seasonally and

224 spatially across the archipelago (Cypher et al. 2014). Beetles, deer mice, (Peromyscus

225 maniculatus), lizards, jerusalem crickets (Stenopalmatus spp.), terrestrial snails, and a number of

226 native and non-native fruits are currently important resources for island foxes (Cypher et al.,

227 2014). Island foxes also consume birds and scavenge livestock or ungulate carcasses when

228 present (Laughrin, 1977; Cypher et al., 2014). Cypher et al. (2014) also found trace amounts of

229 pinniped remains ( $<5$ occurrences/season) in island fox scat from San Nicolas, San Miguel, San

230 Clemente and Santa Catalina, suggesting some marine dietary input. We predicted that ancient

231 island foxes would also show a high degree of isotopic variation since most fox species,

232 including mainland gray foxes, are opportunistic omnivores (Cunningham et al., 2006; Fritzell,

233 1988). 
Island foxes are morphologically similar, yet considerably smaller $(\sim 30 \%)$, than mainland

235 gray foxes, raising the possibility that the fox has been on the islands for a significant time to

236 undergo dwarfing. However, rapid morphological change is possible and can occur within time

237 periods of centuries or less (Cuarón et al., 2004; Gompper et al., 2006). All known ancient and

238 modern fox specimens are indicative of small fox size and there is a lack of evidence in the fossil

239 record that island foxes have undergone dramatic morphological change over the past 7000 years

240 (Collins, 1993, 1991a, 1991b). Despite claims of the occurrence of fossil island foxes as old as

24140,000 or 16,000 years ago that date to prior to human arrival (Collins, 1991a; Guthrie, 1993;

242 Orr, 1968), direct AMS dating and re-analysis of these specimens demonstrated that foxes

243 appeared on the islands around $\sim 7100$ cal BP, about the same time dogs appear in the

244 archaeological record of the Channel Islands (Hofman et al., 2015b; Rick et al., 2009, 2008).

245 There is also no archaeological or paleontological evidence of island fox ancestors on the

246 islands, such as a larger gray fox from mainland California (Collins, 1993, 1991a, 1991b; Rick et

247 al., 2009).

248 A growing body of evidence suggests that Native Americans may have first introduced

249 foxes from the mainland to the Channel Islands. Rick et al. (2009) suggest that a human

250 translocation is supported by their widespread distribution; their absence in Pleistocene fossil

251 deposits and very early archaeological components on the islands; the significance of foxes in

252 Native American religion and ceremony (including over 51 fox burials - described in Collins

253 1991b); use of fox pelts by people; the demographic decline of ground nesting birds in deposits

254 following hypothesized early Holocene fox colonization; and, evidence for rapid morphological

255 change among mammals, including domestic dogs (Collins, 1993, 1991a, 1991b; Rick et al.,

256 2009). While there is little evidence of human consumption of island foxes (Collins, 1991b), 
257 island fox bones have been recovered in a variety of archaeological contexts including middens

258 or refuse piles, as well as intentional burials of foxes, some of which are associated with human

259 burials (Collins, 1991a, 1991b; Hofman et al., 2015b; Vellanoweth, 1998; Vellanoweth et al.,

260 2008). Collectively, these data suggest a diverse set of human-fox interactions over time.

261 Nonetheless, significant questions remain about how ancient peoples and landscape change

262 affected island fox populations on the Channel Islands over the millennia.

263 3. Materials and methods

2643.1 Specimens

265 Paleontological, archaeological, historical, and recent island fox and mainland gray fox

266 bones were obtained from the collections at Santa Barbara Museum of Natural History, National

267 Museum of Natural History, California State University, Los Angeles, California State

268 University, Northridge and Catalina Island Museum (Table 1 and S1). Paleontological and

269 archaeological island fox samples $(n=67)$ come from 25 different archaeological or subfossil

270 localities, or approximately half of the sites where foxes have been identified ( $n=53)$. In selecting

271 prehistoric fox samples, we surveyed published and unpublished accounts of island and gray

272 foxes, investigated museum collections, and contacted colleagues to ensure that we had the

273 widest temporal and spatial coverage possible. Our goals were to make sure that we had samples

274 from the potentially oldest foxes on each island and had adequate diachronic coverage. Although

275 intentional fox burials $(n>51)$ have been recovered on the southern and northern islands (see

276 Collins 1991b), the vast majority of archaeological specimens represent a single bone or small

277 number of bones from unknown or poorly documented contexts. This makes our efforts to

278 associate these materials with human activity challenging for understanding fox diet and their

279 relationships with humans. We were able to sample a number of the possible fox burials $(n=25)$, 
280 although not all burials were available for this study. Island foxes from the late 19th century

$281(n=33)$ and both island $(n=114)$ and gray foxes $(n=24)$ from the 20th century fill in more recent

282 time gaps.

283 Stringent precautions were taken to ensure that any potential for contamination was

284 reduced during fox bone sampling. Specimens were handled with gloves, and all equipment and

285 table surfaces were cleaned with bleach in between each sample. To obtain samples for stable

286 isotope analysis and AMS ${ }^{14} \mathrm{C}$ dating, a small (ca. 100-400 mg) fragment of bone was removed

287 using a clean razor blade, tweezers, or a new Dremel rotary cutting wheel. When crania were

288 present, bone was sampled from nasal turbinates or the internal tentorium plate near the base of

289 the cranium. In some cases, only long bone fragments were available and were cut with a Dremel

290 rotary tool. For archaeological specimens, we sampled different excavation units and, when

291 possible, the same element and side to minimize the possibility of sampling the same individual.

\section{3.2 AMS radiocarbon dating}

293 Eight AMS radiocarbon dates on island fox bones have been reported previously (Hofman

294 et al., 2015b; Rick et al., 2009; Shelley, 2001). To expand on these data, AMS radiocarbon dates

295 were obtained for 21 additional island fox bones with the aim of documenting the antiquity of

296 island foxes and the chronological age of individual specimens with limited context. Samples

297 were chosen to potentially represent some of the oldest island fox remains or sites with long

298 occupational histories and complex stratigraphy. These include specimens from SCAI-17, SRI-1,

299 SRI-3, and SRI-5, SCRI-333, and SMI-1 and SMI-261, that have trans-Holocene or early

300 Holocene deposits and fox remains that came from the surface or unknown contexts (Table 1).

301 Bone fragments of 19 foxes were sent to the Oxford Radiocarbon Accelerator Unit

302 (ORAU) at the University of Oxford (Ramsey et al., 2007a, 2007b). A juvenile dog from a site 
on San Clemente (SCLI-1524) with 11 canid ritual burials (including 6 foxes) was also dated at

304 ORAU to determine whether foxes and dogs were interred simultaneously. Two fox samples

305 (SRI-XX and SNI-7) were sent to Beta Analytic. All bones were pretreated using ultrafiltration

306 techniques (except SRI-XX, which did not have enough sample for ultrafiltration) and collagen

307 was extracted and analyzed for ${ }^{14} \mathrm{C}$ dating. All dates were calibrated using OxCal v. 4.2

308 (Ramsey, 2013, 2009). As some foxes may have consumed high amounts of marine resources,

309 which would require a marine reservoir correction $(\Delta \mathrm{R}), \delta^{13} \mathrm{C}$ values were measured in each

310 specimen independently from the radiocarbon analysis. None of the specimens required a $\Delta \mathrm{R}$

311 correction. A previously reported date for a fox from SNI-11 without a $\delta^{13} \mathrm{C}$ value was corrected

$312(\Delta \mathrm{R}=261 \pm 21$; Jazwa et al., 2012) due to evidence of marine diet in archaeological foxes on San

313 Nicolas Island. All dates were calibrated using the Intcal13 dataset, except for the fox from SNI-

314 11, which used the Marine13 calibration dataset (Reimer et al., 2013).

\subsection{Stable isotope analysis}

316 For carbon $\left(\delta^{13} \mathrm{C}\right)$ and nitrogen $\left(\delta^{15} \mathrm{~N}\right)$ analysis, dog $(n=1)$, gray fox $(n=24)$, and island fox

$317(n=202)$ bone fragments were demineralized in $0.5 \mathrm{~N}$ hydrochloric acid $(\mathrm{HCl})$ for $\sim 12-15 \mathrm{hr}$ at

$3185^{\circ} \mathrm{C}$. The resulting material was soaked in a 2:1 chloroform/methanol solvent solution for $\sim 72$

319 hours to remove lipids and then lyophilized. Freeze-dried sub-samples $(\sim 0.5 \mathrm{mg})$ of bone

320 collagen were sealed in tin boats and $\delta^{13} \mathrm{C}$ and $\delta^{15} \mathrm{~N}$ values were measured using a Costech

321 elemental analyzer coupled to a Finnigan Delta Plus isotope ratio mass spectrometer at the

322 University of Wyoming Stable Isotope Facility (Laramie, WY). Stable isotope results are

323 expressed as delta $(\delta)$ values: $\delta^{13} \mathrm{C}$ or $\delta^{15} \mathrm{~N}=1000 *\left[\left(\mathrm{R}_{\text {sample }} / \mathrm{R}_{\text {standard }}\right)-1\right]$, where $\mathrm{R}_{\text {sample }}$ and

$324 R_{\text {standard }}$ are the ${ }^{13} \mathrm{C} /{ }^{12} \mathrm{C}$ or ${ }^{15} \mathrm{~N} /{ }^{14} \mathrm{~N}$ ratios of the sample and standard, respectively. $\delta$ values are

325 expressed as parts per thousand or per mil (\%). The internationally accepted standards are 
326 Vienna-Pee Dee Belemnite limestone (V-PDB) for $\delta^{13} \mathrm{C}$ and atmospheric $\mathrm{N}_{2}$ for $\delta^{15} \mathrm{~N}$. Fox

327 samples from the 1860 s to the present were corrected for the Suess effect following equations in

328 Francey et al. (1999) and Wiley et al. (2013). Historic museum samples without a collection year

329 were corrected by $0.5 \%$. Previously reported stable isotope data were compiled for the temporal

330 and spatial comparison to human $(n=349), \operatorname{dog}(n=19)$, and island fox $(n=12)$ isotope values

331 (Goldberg, 1993; Rick et al., 2011; Smith, 2013).

332 To explore the utility of the CSA in detecting human provisioning of island foxes, bone

333 collagen $\delta^{13} \mathrm{C}$ or $\delta^{15} \mathrm{~N}$ data were used to calculate standard ellipse areas of humans, dogs, and

334 foxes from archaeological, historic, and recent contexts using the Stable Isotope Bayesian

335 Ellipses in R (Jackson et al., 2011; Parnell, 2011), a tool in the R package Stable Isotope

336 Analysis in R (SIAR, Jackson, 2010). If an individual fox fell within the human or dog ellipse, it

337 was labeled as potentially provisioned. In some cases, we combined data for human and dogs to

338 test whether a shared group included any fox data points. To compare foxes between time points

339 and islands we conducted an analysis of variance as implemented in R v3.2.3 (R Core Team,

340 2015).

341 4. Results

3424.1 Island fox chronology

343 AMS ${ }^{14} \mathrm{C}$ dates from 19 island foxes in this study complement previously published data

344 (Hofman et al., 2015b; Rick et al., 2009; Shelley, 2001), giving a total of 29 directly-dated island

345 fox bones (Table 1). Despite targeting potentially terminal Pleistocene, early Holocene ( 11,700 -

$3467000 \mathrm{cal} \mathrm{BP})$, and middle Holocene ( 7000-3500 cal BP) contexts, our AMS ${ }^{14} \mathrm{C}$ dating results

347 support a largely late Holocene (3500-200 cal BP) record of island foxes on all the islands 
348 (Figure 2, Table S2). We identified considerable variation between inferred archaeological site

349 chronologies from published AMS dates and the AMS date of the island foxes recovered in some

350 sites. In a few cases (SRI-1, SRI-3, and SRI-4), fox AMS dates are considerably younger than

351 the known chronology of the site (Table 1). The earliest evidence of the island fox comes from

352 an archaeological site (SMI-1) overlooking Cuyler Harbor on San Miguel and dates to 7310-

$3537170 \mathrm{cal} \mathrm{BP}$, which is comparable in age to a previously reported date from a SMI subfossil

354 locality of V-7C (Rick et al. 2009). Early dates from Santa Cruz come from the middle/late

355 Holocene site of SCRI-333 and date to $6180-5960 \mathrm{cal} \mathrm{BP}$. On the southern islands, the oldest fox

356 date comes from Catalina (SCAI-17) and dates to 5460-5310 cal BP. On San Nicolas, the oldest

357 fox dates to 5070-4790 cal BP (SNI-11) and is contemporaneous with a fox auditory bulla from

358 SNI-161 that has not been directly dated but has good associated ${ }^{14} \mathrm{C}$ dates (Vellanoweth, 1998);

359 without the marine correction this fox from SNI-11 could be as old as 5860-5590 cal BP. The

360 earliest directly dated fox on San Clemente dates to 2300-2200 cal BP.

361 We report the first documented record of an Island fox on Anacapa Island. Island foxes

362 are not currently present on Anacapa or known from previous archaeological or paleontological

363 research. Five island fox bones (broken proximal left femur, matching broken distal left femur,

364 metarsal, rib, proximal tibia), perhaps representing a single individual, were recovered from

365 ANI-2, a shell midden on East Anacapa occupied between about 3250-2710 cal BP (see Jew et

366 al. 2015; Reeder and Rick 2009). This island fox bone was directly dated to 3210-3010 cal BP

367 and fits well within the site chronology.

$368 \quad 4.2$ Island fox stable isotopes and diet

369 We compared island fox, dog, and human isotope values to test the hypothesis that

370 humans provisioned island fox populations (Figure 3) by quantifying isotope niche width with 
371 calculations of standard ellipse area (SEA), sample size corrected standard ellipse area (SEAc),

372 and the overlap between the SEAc of two groups (Table 2, Figure S1). Isotope niche width varies

373 considerably between islands and species. Ancient human diet varied $\left(\delta^{13} \mathrm{C}:-19.9 \%\right.$ to $-8.7 \%$,

$374 \delta^{15} \mathrm{~N}$ : 4.4\%o to 23.0\%; Goldberg, 1993) on Santa Rosa, Santa Cruz, San Nicolas, San Clemente

375 and especially on the mainland where larger isotopic variation suggests a more mixed diet of

376 terrestrial and marine resources; SEAc was $6.5 \%^{2}$ and $4.9 \%^{2}$ on the mainland and islands

377 respectively. On the islands, isotope data confirmed that ancient peoples consumed a large

378 proportion of marine resources supplemented by plants (see Gill 2014). Ancient dogs from San

379 Clemente, San Nicolas and Santa Rosa clustered closely with humans but only on San Nicolas

380 did the standard ellipses for dogs overlap with humans (Table 2). Isotope values of most island

381 foxes differed from those of humans and dogs, although we documented variation between

382 islands, time points (Figure 3 and 4) and SEAc estimates (Table 2). Island foxes on San Nicolas

383 and San Clemente had the most variation in $\operatorname{diet}$ (SEAc of $14.0 \%^{2}$ and $12.8^{*} \%^{2}$, respectively)

384 and provided the strongest evidence that foxes were consuming marine resources (Figure 3 and

385 5). Several San Nicolas, Santa Rosa and San Clemente fox samples show overlapping isotope

386 values with those of humans (Figure 3); however, there was no overlap in SEAc between foxes

387 and humans and/or dogs.

$388 \quad$ Fox $\delta^{13} \mathrm{C}$ and $\delta^{15} \mathrm{~N}$ values differ significantly between islands $\left(\delta^{13} \mathrm{C}: \mathrm{F}_{(7,232)}=8.97\right.$, $389 \mathrm{P}<0.001$ and $\left.\delta^{15} \mathrm{~N}: \mathrm{F}_{(7,232)}=24.39, \mathrm{P}<0.001, n=240\right)$ and time period on Santa Cruz $\left(\delta^{13} \mathrm{C}\right.$ :

$390 \quad \mathrm{~F}_{(3,24)}=6.88, \mathrm{P}<0.01$ and $\left.\delta^{15} \mathrm{~N}: \mathrm{F}_{(3,24)}=4.059, \mathrm{P}<0.05, n=28\right)$ and San Nicolas $\left(\delta^{13} \mathrm{C}: \mathrm{F}_{(2,50)}=\right.$ $39112.87 \mathrm{P}<0.001$ and $\left.\delta^{15} \mathrm{~N}: \mathrm{F}_{(2,50)}=26.32, \mathrm{P}<0.001, n=53\right)$ and just in $\delta^{13} \mathrm{C}$ on Santa Catalina $392\left(\mathrm{~F}_{(2,18)}=5.561, \mathrm{P}<0.05, n=21\right)$, San Clemente $\left(\mathrm{F}_{(2,27)}=7.119, \mathrm{P}<0.01, n=30\right)$, and San Miguel $393\left(\mathrm{~F}_{(5,30)}=5.65, \mathrm{P}<0.001, n=35\right)$. On the northern islands, small temporal differences in $\delta^{15} \mathrm{~N}$ values 
394 were observed on San Miguel where late and middle Holocene foxes had higher $\delta^{15} \mathrm{~N}$ values in 395 comparison to earlier and later time periods (Figure 4). On Santa Cruz and Santa Rosa, there is

396 very little difference in isotope values between time periods, although $19^{\text {th }}$ century samples from 397 Santa Rosa showed more variability in $\delta^{13} \mathrm{C}$ and $\delta^{15} \mathrm{~N}$.

398 The southern islands showed a dramatically different pattern. On San Clemente, 399 archaeological, historic, and recent foxes have much higher $\delta^{15} \mathrm{~N}$ values than the northern 400 islands. Late Holocene samples in particular show a unique isotope pattern, with relatively high 401 mean $( \pm \mathrm{SD}) \delta^{13} \mathrm{C}(-19.0 \pm 1.2 \%)$ and $\delta^{15} \mathrm{~N}(14.9 \pm 2.1 \%)$ values. Late Holocene foxes on San 402 Nicolas had higher mean $\delta^{13} \mathrm{C}(-16.0 \pm 1.9 \%)$ values relative to late Holocene San Clemente 403 foxes, but had similar $\delta^{15} \mathrm{~N}$ values. Historic Santa Catalina foxes from the 1800s and 1900s had 404 slightly higher $\delta^{13} \mathrm{C}$ values but similar $\delta^{15} \mathrm{~N}$ values in comparison to Santa Cruz. The best 405 evidence for a temporal change in diet came from San Nicolas, where late Holocene foxes had 406 significantly higher $\delta^{15} \mathrm{~N}$ values and virtually no isotopic overlap with those from the $20^{\text {th }}$ 407 century (Figures 4 and 5).

408 5. Discussion

5.1 Island fox origins, antiquity, and chronology

We identified and dated all island fox remains $(n=29)$ from potentially early

411 archaeological sites and none were older than $7310 \mathrm{cal} \mathrm{BP}$, supporting the pattern found by Rick

412 et al. (2009). This study includes the largest sample available to date and supports the hypothesis

413 that island foxes arrived during the early Holocene. Extensive survey, excavation, and analysis of 414 the late Pleistocene and early Holocene archaeological contexts of the northern Channel Islands 415 (Erlandson et al., 1996, 2011; Rick et al., 2013), as well as paleontological localities have 
416 yielded no other fox remains. Rick et al. (2009) noted that many of the Channel Islands fossil

417 localities were thought to be ancient bald eagle nests (Guthrie, 1993) that likely would have

418 contained remnant prey fox remains if they were available on the islands. While historic and

419 modern bald eagle nests occasionally contain island fox remains (Erlandson et al. 2007,

420 Newsome et al. 2010, Newsome et al., 2015), foxes have not been recovered from Pleistocene

421 fossil contexts. The oldest date of $\sim 7300$ years also fits well with genetic estimates of island and

422 gray fox divergence (Hofman et al., 2015b). Analysis of mitochondrial genomes calibrated with

423 a slightly younger date (7160-6910 cal BP), suggested that island foxes diverged from their

424 mainland progenitor $\sim 9200-7100$ cal BP (Hofman et al., 2015b). This is well after humans first

425 arrived on the Channel Islands ( $13,000 \mathrm{cal} B P)$, although it is still not clear whether foxes

426 originally arrived on the northern islands through a natural or human-assisted dispersal.

427 Our oldest island fox remains come from San Miguel Island (Figure 2A) and support the

428 hypothesis that foxes first arrived to the northern islands and were subsequently introduced to the

429 southern islands. The two early dates from San Miguel predate any dates from the southern

430 islands by $\sim 1500-2000$ years. Foxes may have dispersed naturally to the northern islands during

431 the human era, or been introduced by Native Americans (Hofman et al., 2015b). Depending on

432 when foxes arrived on the northern islands, changes in sea level could have affected their natural

433 dispersal between islands. As noted earlier, the northern islands coalesced into a super-island,

434 Santarosae (see Figure 1), that began to separate into its current configuration of four separate

435 islands around 11,000 cal BP and was completely separated by 9000 cal BP (Muhs et al., 2014,

436 Reeder-Myers et al., 2015). Our earliest AMS dates suggest that foxes arrived well after the

437 islands had separated. However, molecular clock divergence estimates based on the analysis of

438 whole mitogenomes suggest that island and mainland fox populations diverged $~ 9200$ years ago 
439 (95\% HPD: 13,300-6100) (Hofman et al., 2015b), around the time the northern islands were

440 completing their separation into distinct land masses. If foxes arrived after the islands separated,

441 then the most parsimonious explanation for their distribution would be a human-assisted

442 translocation by ancient peoples between the northern islands.

443 The first evidence of foxes on the southern islands comes from remains found on Santa

444 Catalina and San Nicolas that date to 5460-5310 cal BP and 5070-4790 cal BP, respectively.

445 Genetic estimates suggest that southern island lineages diverged from northern lineages $\sim 7100$

446 (95\% HPD: 9000-5200) years ago shortly after foxes arrived on the northern islands (Hofman et

447 al., 2015b). Colonization by rafting on floating vegetation or debris to the three southern islands

448 that are further from the mainland than to the northern islands is unlikely. Our results based on

449 both AMS dates and molecular clock divergence estimates (Hofman et al., 2015b) support a

450 more likely scenario that ancient peoples transported foxes on their vessels to the southern

451 islands soon after their initial arrival on northern islands. If this is true, it lends anecdotal support

452 to the hypothesis that humans first transported foxes to the northern islands.

453 While investigating the contexts of all recorded island fox material, we documented

454 considerable variation between previously reported site chronologies and AMS dates on island

455 fox bones recovered from the same site. For example, 15 AMS dates from SRI-3 suggest a trans-

456 Holocene occupation from 8860-2760 cal BP, but the island fox remains from the site were

457 directly radiocarbon dated to $\sim 300$ years ago. A similar discrepancy between known site

458 chronologies and direct AMS island fox dates was also identified at SRI-1 and SRI-4 (Table 1).

459 Rick et al. (2009) analyzed island foxes from subfossil localities previously reported to be

$460>40,000$ (beyond the limits of radiocarbon dating) and 16,000 years old and documented the

461 same problem as all fox remains from these subfossil localities were dated to the Holocene and 
462 even historic times (Rick et al., 2009; Shelley, 2001). Much of the problem likely stems from the

463 fact that these subfossils and the archaeological specimens noted above were obtained from the

464 surface of a site or from an unknown locality rather than in good stratigraphic context. In one

465 case, fox remains recovered by Orr (1968) at a subfossil locality on Santa Rosa Island were

466 argued to be at least 16,000 years old. These data were used to support a pre-human colonization

467 of the northern Channel Islands by foxes (Collins, 1991a; Orr, 1968) and were used to calibrate

468 many of the initial genetic studies of island foxes (Aguilar et al., 2004; Gilbert et al., 1990;

469 Wayne et al., 1991). However, direct AMS dating of this bone indicated that it was only 1510-

4701280 years old and likely from a fox bone intruded into Pleistocene deposits or whose

471 stratigraphic association was misidentified (Rick et al., 2009; Shelley, 2001). These findings

472 underscore the importance of direct AMS ${ }^{14} \mathrm{C}$ dating of island foxes and other animal bone

473 samples when interpreting species chronology, biogeography, and dispersal.

$474 \quad 5.2$ Ancient Island Fox Diets

475

5.2.1 Early and middle Holocene

We explored changes in island fox diet spanning 7300 years and seven islands, including

478 Anacapa, where foxes had not been previously reported. We hypothesized that if humans

479 introduced foxes to the northern islands, early fox remains might have isotope values similar to

480 humans or dogs, which in this context would indicate consumption of marine resources with high

$481 \quad \delta^{13} \mathrm{C}$ and $\delta^{15} \mathrm{~N}$ values relative to terrestrial foods. However, there is no overlap between the

482 SEAc of human/dogs and foxes on any of the islands (Table 2). The earliest fox from San Miguel

483 does not have a marine isotope signature suggestive of anthropogenic resource consumption or

484 provisioning, but instead has isotope values indicative of a terrestrial diet in comparison to foxes

485 from later time periods (Figure 3). On Santa Cruz, a middle Holocene (6180-5950 cal BP) fox 
486 has higher $\delta^{13} \mathrm{C}$ and $\delta^{15} \mathrm{~N}$ values relative to chronologically younger foxes, but there is no 487 definitive evidence of provisioning on Santa Cruz. On the southern islands, the earliest fox on

488 Catalina has isotope values that are slightly higher than those from later periods, however, 489 comparable human data are not available from this island so it is difficult to make an assessment 490 of anthropogenic resource consumption or provisioning. Unfortunately, the earliest fox from San 491 Nicolas (SNI-11, 5070-4790 cal BP) was not available for isotopic analysis. Together our results 492 based on these few data points do not support the scenario that early and middle Holocene foxes 493 were scavenging anthropogenic resources or that ancient peoples were provisioning them.

494 However, just because we did not detect direct human provisioning in these samples, does not 495 preclude an association with humans or an ancient human introduction.

496 Although fox furs may have been important to Native Islanders, another reason why 497 humans would translocate foxes to the Channel Islands was for pest management- - to manage 498 deer mouse populations on islands with few natural predators but contained human settlements 499 rich in refuse (Collins, 1991a; Rick et al., 2009, 2005; Vellanoweth, 1998). If pest control was a 500 factor influencing translocation of foxes, and mice were a large component of their diet, we 501 would not expect to find isotopic signatures of human provisioning. Interference competition 502 with dogs also may have forced many foxes to focus on deer mice and other wild foods rather 503 than human refuse. Even if ancient peoples were not provisioning foxes directly, midden refuse 504 could have attracted mice, which was likely a dietary staple for foxes (Cypher et al., 2014).

505 However, distinguishing between intentional or accidental pest management is difficult in the 506 archaeological record. 
In the late Holocene (3500-200 cal BP), we observed high $\delta^{13} \mathrm{C}$ and $\delta^{15} \mathrm{~N}$ values in island

511 foxes from San Nicolas Island that overlapped with isotope values of humans, suggesting that

512 foxes consumed significant amounts of marine resources. However we did not find any overlap

513 in the niche width estimates using standard ellipses between human and fox populations. On

514 Santa Rosa, a fox initially associated with the Pleistocene Upper Tecolote member, but dated to

515 much later (1510-1280 cal BP), has isotope values similar to some humans, although not within

516 the SEAc for humans as a group (Figure 3). Human population sizes on the islands increased

517 during the late Holocene as people settled in large sedentary villages (Kennett, 2005). Higher

518 population densities producing more refuse could provide a valuable resource for island foxes

519 living near a village. Nevertheless, it is difficult to distinguish between scavenging from human

520 refuse and intentional human provisioning, yet either way, humans may have influenced fox diet.

521 Late Holocene foxes from San Nicolas have considerable isotopic variation with $\delta^{13} \mathrm{C}$ and

$522 \delta^{15} \mathrm{~N}$ values varying by $7.3 \%$ and $9.7 \%$ respectively. Late Holocene foxes from SNI-7, where

523 the presence of nearly 20 island fox skulls in a single site may suggest production of fox capes or

524 blankets (see Collins, 1991b), have relatively high $\delta^{13} \mathrm{C}$ and $\delta^{15} \mathrm{~N}$ values, but lie just below the

525 standard ellipse for human/dogs (Figure 3 and 5). However, we detected three foxes with isotope

526 values suggestive of human provisioning with marine resources at the Tule Creek Village site

527 (SNI-25). The east locus of SNI-25 has artifacts and features associated with ceremonial events,

528 including shell effigies, feasting pits, and animal burials (Smith, 2013). Three disarticulated

529 foxes from the east locus have higher mean $( \pm \mathrm{SD}) \delta^{13} \mathrm{C}(-12.2 \pm 1.4 \%)$ and $\delta^{15} \mathrm{~N}(19.2 \pm 2.1 \%$ )

530 values when compared to three foxes from the south locus with mean $\delta^{13} \mathrm{C}$ and $\delta^{15} \mathrm{~N}$ values of -

$531 \quad 15.6 \pm 3.2 \%$ and $14.6 \pm 3.3 \%$ respectively (Smith, 2013). The higher isotope values in foxes from

532 the east locus could mean that the animals interred there were provisioned and kept for 
ceremonial purposes. At Teotihuacan in Mexico, some felids (Panthera onca and Puma

534 concolor) intended for sacrifice were first held for several months in captivity, which allowed

535 enough time for bone collagen $\delta^{13} \mathrm{C}$ values to reflect consumption of maize, while other

536 individuals were sacrificed before dietary maize was integrated into this tissue (Sugiyama et al.,

537 2015). These differences may be equivalent to the variability in isotope values from foxes found

538 at a single archaeological site, raising the possibility that some animals were provisioned while

539 others were not, and suggesting that differing cultural practices on the northern and southern

540 islands may have influenced the diet of some late Holocene island foxes.

541 On the southern islands, the Chinigchinich religion, which according to ethnohistoric

542 accounts involved animal sacrifices (Jackson and Castillo, 1996; Raab and Cassidy, 2009), may

543 have played a role in observed island fox dietary patterns. On San Clemente, island foxes were

544 recovered from a ceremonial site (SCLI-1524) possibly associated with the Chinigchinich

545 religion. Excavations within the interior of a circular midden berm surrounding a potential

546 wamkish, or an open area ceremonial site, yielded five dog burials and six fox burials (five

547 juvenile) (Hale and Salls, 2000). We dated three juvenile foxes and one juvenile dog from these

548 burials and the calibrated dates span three non-overlapping time periods (730-670 cal BP (dog),

549 540-500 cal BP (fox), and 430-0 cal BP (double fox burial). These data suggest that people may

550 have buried juvenile canids at this site for several centuries. The youngest fox burial might be

551 associated with the historically described Chinigchinich religion while the earlier dog and fox

552 burials are consistent with late prehistoric animal sacrifice documented in other southern

553 Channel Island sites (see Bartelle et al., 2010; Vellanoweth et al., 2008).

554 Isotope data from these burials are somewhat ambiguous, and may relate to the age of the

555 foxes recovered from this context. In mammals, juveniles typically have higher $\delta^{15} \mathrm{~N}$ values than 
556 adult females (mothers), as mothers catabolize their own tissue to produce milk for their

557 offspring (Fuller et al., 2006; Newsome et al. 2006); the effects of nursing on $\delta^{13} \mathrm{C}$ values is

558 unknown in foxes. The young age of these individuals does not allow us to conclude that there

559 was anthropogenic resource consumption or human provisioning, but suggests that ancient

560 people either had immediately removed these juveniles from their mothers or had the mother on

561 hand to feed her offspring. We can also use age at death to identify the seasonality of this ritual.

562 Although foxes give birth in late April and early May on the northern islands, with mothers

563 lactating for 7-9 weeks and pups emerging from the den in the early summer (Moore and

564 Collins, 1995), parturition seems earlier on the southern islands. Powers (2009) found that foxes

565 had litters from early to mid-March on San Nicolas Island, while Resnick and Andelt (2012)

566 reported that parturition occurred as early as mid-February on San Clemente Island. The juvenile

567 foxes from SCLI-1524 are less than two months of age based on dental eruption (Hale and Salls,

568 2000). Therefore, this ritual can be dated to late spring or early summer depending on parturition

569 date, but possibly as fox pups are emerging from their dens and learning to forage with their

570 parents. These ritual activities on San Clemente, in addition to possible human provisioning in

571 several San Nicolas foxes, indicate that late Holocene people had considerable interaction with

572 island fox populations.

$573 \quad 5.2 .3$ Historic and recent times

574

575

Isotope values of archaeological and late Holocene foxes differ considerably from those

576 collected from $19^{\text {th }}$ and $20^{\text {th }}$ century populations on several of the islands (Figure 4). Historic

577 ranching dramatically transformed island landscapes in the $19^{\text {th }}$ century. On San Nicolas, where

578 there is no overlap in $\delta^{13} \mathrm{C}$ and $\delta^{15} \mathrm{~N}$ SEAc estimates between the late Holocene and the $19^{\text {th }}$

579 century foxes, ranching and the introduction of non-native grasses, may have affected island fox 
580 diet. The most comprehensive study of modern island fox diet to date indicates that as much as

$58145 \%$ of San Nicolas fox diets may include non-native resources (Cypher et al., 2014). On San

582 Clemente, four foxes with higher $\delta^{13} \mathrm{C}$ and $\delta^{15} \mathrm{~N}$ values (similar to humans) date to the late $19^{\text {th }}$

583 and $20^{\text {th }}$ century $(1897 ; 1977 ; 1982 ; 1982)$. San Clemente has been owned and managed by the

584 United States Navy since 1934 and foxes may have been provisioned by sailors stationed on the

585 island. There are also anecdotal accounts that historic ranchers kept island foxes as pets and

586 moved foxes from Santa Catalina to San Clemente (Collins, 1991a; Johnson, 1975). During the

587 course of the twentieth century, human land use shifted from ranching to conservation-oriented

588 management, likely contributing to the minor shifts we see in island fox $\delta^{13} \mathrm{C}$ and $\delta^{15} \mathrm{~N}$ values

589 (Figure 4).

$590 \quad 5.3$ Long-term trends and signatures of marine resource use: human provisioning, scavenging in

591 middens or on the coast

592 Human isotope values on the Channel Islands have relatively high mean $( \pm \mathrm{SD}) \delta^{13} \mathrm{C}$ and

$593 \delta^{15} \mathrm{~N}$ values of $-13.5 \pm 1.4$ and $16.9 \pm 2.2$ respectively, and enrichment in fox bone collagen isotope

594 values to these levels would necessitate the consumption of considerable marine resources. The

595 high $\delta^{13} \mathrm{C}$ and $\delta^{15} \mathrm{~N}$ values in some foxes could be a result of scavenging anthropogenic resources

596 or human provisioning, but they might also be generated through scavenging of marine mammal

597 carrion or other marine resources. We found little evidence of considerable marine resource use

598 by recent fox populations from San Miguel and San Nicolas, which have large pinniped

599 rookeries that produce numerous carcasses. However, as island foxes are territorial and males are

600 intolerant of intruders, only a small proportion of the foxes on these islands - those with home

601 ranges that include beaches that contain large amounts of marine resources (e.g., pinniped

602 rookeries) - would be likely to use marine resources. Further research is required to determine if 
603

604

605

606

607

608

609

610

611

612

613

614

615

616

617

618

619

620

621

622

623

624

625

marine mammal scavenging is responsible for these isotopic patterns, including data on how the habitat composition of fox home ranges affects diet variation, as well as comparisons of ancient samples to isotopic values in bone collagen of modern foxes known to scavenge marine carrion. Long-term patterns in island fox stable isotope values are most consistent on Santa

Catalina and Santa Cruz (Figure 4). Interestingly, in a pairwise analysis of food group contributions in modern island fox scat, Horn's similarity index (0.59) shows that these islands are also similar today (Cypher et al., 2014). Regardless of time period, foxes from San Clemente have higher $\delta^{13} \mathrm{C}$ and $\delta^{15} \mathrm{~N}$ relative to the other islands (Figure 4). Two scenarios could explain this pattern. First, variability in climate and habitats between San Clemente and the other islands could affect resource availability and prey choice, or change the baseline $\delta^{13} \mathrm{C}$ and $\delta^{15} \mathrm{~N}$ composition of primary producers that would in turn label primary consumers that island foxes eat. Second, from the late Holocene through the present, people may have provisioned foxes or foxes scavenged anthropogenic and/or marine resources. For San Clemente we do not have data for foxes prior to $~ 2300-2200 \mathrm{cal} \mathrm{BP}$, or before the human population increased that likely coincided with the development of Chingichngish religious practices. A trend of decreasing $\delta^{13} \mathrm{C}$ and $\delta^{15} \mathrm{~N}$ values is evident on San Nicolas (Figure 5) between the late Holocene and the 1900s. This island provides the best evidence for potential scavenging of Native American refuse or direct human provisioning of foxes, as well as indicating that foxes were eating less marine resources in the wake of early $19^{\text {th }}$ century removal of Native Americans from the island.

\section{Conclusions}

In this study, we analyzed new and previously reported stable isotope values and AMS radiocarbon dates to explore the antiquity of the island fox and the evolution of its diet from its known history of occupation from 7300 years ago to the present. A suite of 29 AMS radiocarbon 
626 dates suggests that the oldest known island fox remains come from San Miguel Island as early as

$627 \sim 7300$ cal BP. We have not necessarily identified the earliest fox on the islands, but these data

628 support previous genetic research and radiocarbon dating that indicate an early to middle

629 Holocene arrival of foxes to the Channel Islands (Hofman et al., 2015b; Rick et al., 2009).

630 We used the Canine Surrogacy Approach to evaluate hypotheses about temporal and

631 spatial variation in island fox diet and human-fox interactions. In general, our data suggest that

632 island fox diets differ substantially from humans and dogs, and that island foxes are not good

633 surrogates for ancient human or dog diets. Beyond the Channel Islands, West and France (2015)

634 also found differences in the isotope signatures of dogs and red foxes (Vulpes vulpes) on Kodiak

635 Island, Alaska, where dogs had evidence for marine resource consumption and foxes had mixed

636 terrestrial and marine signatures. We also detected minimal evidence of anthropogenic (marine-

637 based) resource use by foxes, or human resource provisioning of foxes on the Channel Islands.

638 Exceptions to this pattern might have occurred in the late Holocene on San Nicolas, Santa Rosa,

639 and San Clemente, where a few foxes had isotope values that overlapped with those of humans.

640 These data, however, do support a number of unique human-fox interactions, including

641 ritual sacrifice and potential provisioning. Ancient peoples appear to have ritually sacrificed

642 juvenile foxes on late Holocene San Clemente (Hale and Salls, 2000). On San Nicolas there is

643 evidence of potential resource provisioning of adult foxes, including some from ceremonial or

644 ritual contexts. Although our isotope data do not suggest significant human-fox provisioning on

645 the other islands, more than 50 fox burials and human-associated remains show a ritual

646 interaction between humans and foxes.

647 With a dataset spanning 7300 years and a range of human land use practices, we are able

648 to identify some long-term trends in fox diet. As expected, island foxes exhibited substantial 
dietary variation through time and across space spanning several trophic levels. Despite the

650 dramatic changes that have altered the environmental and cultural landscapes of the Channel

651 Islands during the Holocene (i.e., Native American, ranching, conservation, military use, and

652 tourism), stable isotope analysis demonstrates the generalist foraging behavior of the omnivorous

653 island fox. It remains to be seen how island fox populations will be impacted by future climatic

654 and cultural changes, but the species' generalist/omnivorous foraging behavior may make it

655 resilient to environmental changes that influence resource availability on the Channel Islands.

656

657

658

659

660

661

662

663

664

665

666

667

668

669

670

671

672

673

674

675

676

677

678

679

680

681

682

683

684

685

686

\section{Acknowledgments}

We thank our many collaborators on the Channel Islands and beyond for help in understanding island fox-human relationships. In particular, we thank Christie Boser, Todd Braje, Tim Coonan, Kate Faulkner, Chris Funk, Russell Galipeau, Ann Huston, Julie King, Leslie Reeder-Myers, Kelly Minas, Scott Morrison, Sabrina Shirazi, and Catherine West. Funds for this project were provided by a Smithsonian Institution Grand Challenges Level 2 grant (Rick, Chesser, Fleischer, Hofman, Maldonado, Ralls, and Sillett) and a National Museum of Natural History Small Grant (Rick, Hofman, and Maldonado), as well as a National Science Foundation Dissertation Improvement Grant (Shackel and Hofman, BCS-1338773). We acknowledge the support of our home institutions and thank reviewers and the editorial staff of Quaternary Science Reviews.

Figure 1 Map of the California Channel Islands. Island shape and size are modeled at key time points (Last Glacial Maximum, 10,000 cal BP, and present day). Islands with extant island fox populations are outlined in green.

Figure 2 AMS radiocarbon dates of island foxes. Dates are colored by island and dates with marine calibrations are highlighted in green. Radiocarbon dates are organized by date (Fig. 2A) and by island (Fig. 2B).

Figure 3 Carbon $\left(\delta^{13} \mathrm{C}\right)$ and nitrogen $\left(\delta^{15} \mathrm{~N}\right)$ isotope bivariate plot of archaeological humans, archaeological, historic and modern island foxes and modern mainland gray foxes. Standard ellipse areas (SEA) are shown for each species and island foxes within the human ellipse are outlined in black and juveniles with weaning signatures are outlined in orange.

Figure 4 Carbon $\left(\delta^{13} \mathrm{C}\right)$ and nitrogen $\left(\delta^{15} \mathrm{~N}\right)$ isotope bivariate plot of island and gray foxes by time period.

Figure 5 Carbon $\left(\delta^{13} \mathrm{C}\right)$ and nitrogen $\left(\delta^{15} \mathrm{~N}\right)$ isotope bivariate plot of San Nicolas Island foxes by time period. Island foxes in the late Holocene show evidence of more marine resource use than foxes in the 1900s. 
688 Table S1 Sample ID, sex, uncorrected and corrected carbon $\left(\delta^{13} \mathrm{C}\right)$ and nitrogen $\left(\delta^{15} \mathrm{~N}\right)$ isotope 689 values, species, year and locality of specimens analyzed in this study.

690

691 Table S2 AMS radiocarbon dates of canid samples presented in this study.

692

693 Figure S1 Estimates of the standard ellipse area (SEA) from group comparisons in Figures 3 and

694 5. Black dots represent the mode of Bayesian standard ellipse area (SEAb) with the shaded boxes 695 representing the $50 \%, 75 \%$ and $95 \%$ credible intervals from dark to light grey. The red dot is the 696 corrected standard ellipse area for small sample sizes (SEAc). 
Table 1. Paleontological and Archaeological Island Fox Samples

\begin{tabular}{|c|c|c|c|c|c|c|c|}
\hline Island & Site & $\begin{array}{c}\text { Site } \\
\text { Chronology }\end{array}$ & $\begin{array}{l}\text { Fox } \\
\text { Date }\end{array}$ & $N I S P^{I}$ & $M N I^{2}$ & Reference & Isotope $^{3}$ \\
\hline \multirow{9}{*}{$\begin{array}{c}\text { San } \\
\text { Miguel }\end{array}$} & SMI-1 & $7120-3070$ & $7310-7170$ & 2 & 1 & $\begin{array}{l}\text { Collins (1991a); } \\
\text { Rick et al. 2009 }\end{array}$ & 1 \\
\hline & SMI-87 & $4830-2360$ & & 1 & 1 & $\begin{array}{l}\text { Rick et al. } \\
2009\end{array}$ & \\
\hline & SMI-261 & $12,600-550$ & $\begin{array}{l}980-920 \\
960-800\end{array}$ & 13 & 1 & $\begin{array}{l}\text { Collins (1991a); } \\
\text { Rick et al. 2009 }\end{array}$ & 2 \\
\hline & SMI-470 & $\begin{array}{l}\text { 4410-3940; } \\
\text { 460-Historic }\end{array}$ & & 1 & 1 & Rick et al. 2009 & \\
\hline & SMI-525 & $3290-470$ & & 1 & 1 & $\begin{array}{l}\text { Collins (1991a); } \\
\text { Rick et al. 2009 }\end{array}$ & - \\
\hline & SMI-603 & $8500-910$ & & 1 & 1 & Rick et al. 2009 & 1 \\
\hline & $\begin{array}{l}\text { SMI- } \\
\text { Locality } \\
7 C^{4}\end{array}$ & $\begin{array}{l}\text { Pleistocene/ } \\
\text { Holocene }\end{array}$ & $7160-6910$ & 1 & 1 & $\begin{array}{l}\text { Guthrie (1993); } \\
\text { Rick et. al } 2009\end{array}$ & \\
\hline & $\begin{array}{l}\text { SMI- } \\
\text { Locality } \\
10^{4}\end{array}$ & $\begin{array}{l}\text { Pleistocene/ } \\
\text { Holocene }\end{array}$ & $950-800$ & 6 & 1 & $\begin{array}{l}\text { Guthrie (1993); } \\
\text { Rick et. al. } \\
2009\end{array}$ & \\
\hline & $\begin{array}{l}\text { SMI- } \\
\text { Locality } \\
11^{4}\end{array}$ & $\begin{array}{l}\text { Pleistocene/ } \\
\text { Holocene }\end{array}$ & $300-0$ & 1 & 1 & $\begin{array}{l}\text { Guthrie (1993); } \\
\text { Rick et. al. } \\
2009\end{array}$ & \\
\hline \multirow{11}{*}{$\begin{array}{c}\text { Santa } \\
\text { Rosa } \\
\text { Island }\end{array}$} & SRI-1 & $\begin{array}{c}9390-1980 \\
\text { cal BP }\end{array}$ & $\begin{array}{c}1290-1180 \\
480-320\end{array}$ & 9 & 6 & $\begin{array}{l}\text { Collins (1991a); } \\
\text { Rick et al. 2009 }\end{array}$ & 2 \\
\hline & SRI-2 & 2460-Historic & $530-480$ & $>16$ & 9 & $\begin{array}{r}\text { Collins (1991a } \\
\& \text { b); Rick et al. } \\
2009\end{array}$ & 5 \\
\hline & SRI-3 & $8860-2760$ & $310-0$ & 3 & 2 & $\begin{array}{l}\text { Collins (1991a); } \\
\text { Rick et al. 2009 }\end{array}$ & 2 \\
\hline & SRI-4 & $7560-1830$ & $660-550$ & 1 & 1 & $\begin{array}{l}\text { Collins (1991a); } \\
\text { Rick et al. 2009 }\end{array}$ & 1 \\
\hline & SRI-25 & $\mathrm{n} / \mathrm{a}$ & & 2 & 1 & $\begin{array}{l}\text { Shelley (2001); } \\
\text { Rick et al. 2009 }\end{array}$ & - \\
\hline & SRI-41 & $5610-1040$ & $3830-3640$ & 2 & 1 & $\begin{array}{l}\text { Collins (1991a); } \\
\text { Rick et al. 2009 }\end{array}$ & 1 \\
\hline & SRI-168 & $\begin{array}{c}\text { Late } \\
\text { Holocene }\end{array}$ & & 2 & & & 1 \\
\hline & SRI-347 & $\mathrm{n} / \mathrm{a}$ & & 1 & & & - \\
\hline & SRI-365 & $\mathrm{n} / \mathrm{a}$ & & $\mathrm{n} / \mathrm{a}$ & 1 & Rick et al. 2009 & - \\
\hline & SRI-670 & $\begin{array}{c}\text { Late } \\
\text { Holocene }\end{array}$ & & 2 & & & 2 \\
\hline & SRI-XX & $\begin{array}{c}\text { Late } \\
\text { Holocene }\end{array}$ & $530-340$ & $\mathrm{n} / \mathrm{a}$ & $\mathrm{n} / \mathrm{a}$ & & 3 \\
\hline
\end{tabular}




\begin{tabular}{|c|c|c|c|c|c|c|c|}
\hline & $\begin{array}{l}\text { Upper } \\
\text { Tecolote }^{4}\end{array}$ & $\begin{array}{c}\text { Terminal } \\
\text { Pleistocene }\end{array}$ & $1510-1280$ & 3 & 1 & $\begin{array}{r}\text { Collins (1991a); } \\
\text { Shelley 2001; } \\
\text { Rick et al. } 2009\end{array}$ & 1 \\
\hline \multirow{13}{*}{$\begin{array}{l}\text { Santa } \\
\text { Cruz } \\
\text { Island }\end{array}$} & SCRI-1 & 2670-Historic & & 2 & & & 2 \\
\hline & SCRI-122 & $\begin{array}{c}\text { Late } \\
\text { Holocene }\end{array}$ & & 2 & 2 & $\begin{array}{l}\text { Collins (1991a); } \\
\text { Rick et al. } 2009\end{array}$ & - \\
\hline & SCRI-131 & $\begin{array}{c}\text { Late } \\
\text { Holocene }\end{array}$ & & 2 & 2 & $\begin{array}{l}\text { Collins (1991a); } \\
\text { Rick et al. } 2009\end{array}$ & - \\
\hline & SCRI-147 & $\begin{array}{c}\text { Late } \\
\text { Holocene }\end{array}$ & & $>18$ & 5 & $\begin{array}{l}\text { Collins (1991a); } \\
\text { Rick et al. 2009 }\end{array}$ & - \\
\hline & SCRI-206 & $\mathrm{n} / \mathrm{a}$ & & 1 & 1 & $\begin{array}{l}\text { Collins (1991a); } \\
\text { Rick et al. 2009 }\end{array}$ & - \\
\hline & $\begin{array}{l}\text { SCRI-236 } \\
(\mathrm{SCRI}-86)\end{array}$ & $5320-500$ & & 7 & 6 & $\begin{array}{l}\text { Collins (1991a); } \\
\text { Rick et al. } 2009\end{array}$ & - \\
\hline & SCRI-240 & $5570-320$ & & 5 & $\mathrm{n} / \mathrm{a}$ & $\begin{array}{l}\text { Noah }(2005) ; \\
\text { Rick et al. } 2009\end{array}$ & - \\
\hline & SCRI-257 & $\begin{array}{c}\text { Late } \\
\text { Holocene }\end{array}$ & & 4 & & & 4 \\
\hline & SCRI-306 & $760-270$ & & $\mathrm{n} / \mathrm{a}$ & $\mathrm{n} / \mathrm{a}$ & $\begin{array}{l}\text { Arnold (1987); } \\
\text { Rick et al. } 2009\end{array}$ & - \\
\hline & $\begin{array}{l}\text { SCRI- } \\
328 / 330 \\
\end{array}$ & 910-Historic & & 9 & $\mathrm{n} / \mathrm{a}$ & $\begin{array}{l}\text { Noah }(2005) ; \\
\text { Rick et al. } 2009\end{array}$ & - \\
\hline & $\begin{array}{l}\text { SCRI-333 } \\
\text { (SCRI-3) } \\
\end{array}$ & $6280-1090$ & $\begin{array}{c}6180-5950 ; \\
2750-2510 \\
\end{array}$ & 45 & 13 & $\begin{array}{l}\text { Collins (1991a); } \\
\text { Rick et al. } 2009\end{array}$ & 2 \\
\hline & $\begin{array}{l}\text { SCRI-474 } \\
\text { (SCRI-100) }\end{array}$ & $\begin{array}{c}\text { Late } \\
\text { Holocene }\end{array}$ & & $>46$ & 11 & $\begin{array}{l}\text { Collins (1991a); } \\
\text { Rick et al. } 2009\end{array}$ & - \\
\hline & SCRI-496 & $\begin{array}{c}\text { Late } \\
\text { Holocene }\end{array}$ & & 4 & & & 2 \\
\hline $\begin{array}{l}\text { Anacapa } \\
\text { Island }\end{array}$ & ANI-2 & $3250-2710$ & $3210-3010$ & 1 & & $\begin{array}{l}\text { Reeder and } \\
\text { Rick 2009; Jew } \\
\text { et al. } 2015\end{array}$ & 1 \\
\hline \multirow{4}{*}{$\begin{array}{c}\text { Santa } \\
\text { Catalina } \\
\text { Island }\end{array}$} & SCAI-17 & $\begin{array}{c}5990-4270 ; \\
1520-470 \\
\end{array}$ & $5460-5310$ & 3 & 2 & $\begin{array}{l}\text { Collins (1991a); } \\
\text { Rick et al. } 2009\end{array}$ & 1 \\
\hline & SCAI-26 & 720-Historic & & 22 & & Porcasi 2012 & - \\
\hline & SCAI-32 & $\begin{array}{c}\text { Late } \\
\text { Holocene }\end{array}$ & & 51 & & Porcasi 2014 & - \\
\hline & SCAI-137 & Historic & & 3 & 1 & $\begin{array}{l}\text { Collins (1991a); } \\
\text { Rick et al. } 2009\end{array}$ & - \\
\hline San & SNI-7 & $\begin{array}{c}\text { Late } \\
\text { Holocene }\end{array}$ & $2110-1900$ & $\mathrm{n} / \mathrm{a}$ & 20 & $\begin{array}{l}\text { Collins (1991a } \\
\text { \& b); Rick et al. }\end{array}$ & 13 \\
\hline
\end{tabular}




\begin{tabular}{|c|c|c|c|c|c|c|c|}
\hline \multirow{9}{*}{$\begin{array}{l}\text { Nicolas } \\
\text { Island }\end{array}$} & \multicolumn{7}{|c|}{2009} \\
\hline & SNI-11 & $7160-330$ & $5070-4790$ & $>5$ & 2 & $\begin{array}{l}\text { Collins (1991a); } \\
\text { Rick et al. } \\
\text { 2009; Shelley } \\
2001\end{array}$ & - \\
\hline & SNI-16 & $\begin{array}{c}\text { Late } \\
\text { Holocene }\end{array}$ & $1870-1730$ & $\mathrm{n} / \mathrm{a}$ & $\mathrm{n} / \mathrm{a}$ & & 3 \\
\hline & SNI-25 & 740-Historic & $\begin{array}{l}530-490 \\
500-320\end{array}$ & $\mathrm{n} / \mathrm{a}$ & 10 & Rick et al. 2009 & 9 \\
\hline & SNI-51 & $2870-1720$ & & 2 & 1 & $\begin{array}{l}\text { Collins (1991a); } \\
\text { Rick et al. 2009 }\end{array}$ & - \\
\hline & SNI-102 & $2870-2440$ & & $\mathrm{n} / \mathrm{a}$ & $\mathrm{n} / \mathrm{a}$ & $\begin{array}{l}\text { Martz (2005); } \\
\text { Rick et al. 2009 }\end{array}$ & - \\
\hline & SNI-119 & $\mathrm{n} / \mathrm{a}$ & & 4 & 1 & $\begin{array}{l}\text { Collins (1991a); } \\
\text { Rick et al. 2009 }\end{array}$ & - \\
\hline & SNI-160 & $1810-800$ & & $\mathrm{n} / \mathrm{a}$ & $\mathrm{n} / \mathrm{a}$ & $\begin{array}{l}\text { Martz (2005); } \\
\text { Rick et al. 2009 }\end{array}$ & - \\
\hline & SNI-161 & $5450-4710$ & & 1 & 1 & $\begin{array}{l}\text { Vellanoweth } \\
\text { (1998); Rick et } \\
\text { al. 2009 }\end{array}$ & - \\
\hline \multirow{6}{*}{$\begin{array}{c}\text { San } \\
\text { Clemente }\end{array}$} & SCLI-43 & $12,540-510$ & $\begin{array}{l}2200-2300 \\
1810-1610\end{array}$ & $>28$ & 4 & & 1 \\
\hline & SCLI-48 & $\mathrm{n} / \mathrm{a}$ & & 1 & 1 & $\begin{array}{l}\text { Collins (1991a); } \\
\text { Rick et al. 2009 }\end{array}$ & - \\
\hline & SCLI-1215 & $5440-310$ & & $>2$ & 2 & $\begin{array}{l}\text { Collins (1991a); } \\
\text { Rick et al. 2009 }\end{array}$ & - \\
\hline & SCLI-1531 & $\mathrm{n} / \mathrm{a}$ & $530-490$ & 3 & & & 1 \\
\hline & SCLI-1524 & $\begin{array}{l}2360- \\
\text { Historic }\end{array}$ & $\begin{array}{c}540-500 \\
430-150: \\
300-0\end{array}$ & 8 & & $\begin{array}{l}\text { Collins (1991a); } \\
\text { Rick et al. } 2009\end{array}$ & 3 \\
\hline & & & & & & Total & 64 \\
\hline
\end{tabular}

${ }^{1}$ Minimum number of individuals (MNI) as identified by the cited publications or this study.

$700{ }^{2}$ Number of identified specimens (NISP) as identified by the cited publications or this study.

$701{ }^{3}$ Number of samples included in our isotope analyses from each site.

$702{ }^{4}$ These sites are paleontological contexts. 
715 Table 2. Standard Ellipse Area for Humans, Dogs, Island Foxes and Gray Foxes

\begin{tabular}{|c|c|c|c|c|}
\hline Island & Group & SEAb $^{1}$ & SEAc $^{2}$ & SEAc Overlap $^{3}$ \\
\hline \multirow{2}{*}{ Mainland } & Gray Fox & 16.9 & 17.7 & \multirow[b]{2}{*}{0.0} \\
\hline & Human & 6.5 & 6.5 & \\
\hline San Miguel & Island Fox & 4.3 & 4.4 & \\
\hline \multirow{3}{*}{ Santa Rosa } & Dog & 1.2 & 1.7 & \multirow[b]{3}{*}{0.0} \\
\hline & Human & 2.9 & 3.0 & \\
\hline & Island Fox & 6.3 & 6.4 & \\
\hline \multirow{2}{*}{ Santa Cruz } & Human & 3.4 & 3.5 & \multirow[b]{2}{*}{0.0} \\
\hline & Island Fox & 2.2 & 2.2 & \\
\hline \multirow{7}{*}{ San Nicolas Island } & Dog & 6.0 & 6.6 & \multirow{2}{*}{4.0 (Dog-Human) } \\
\hline & Human & 8.1 & 8.6 & \\
\hline & Island Fox & 13.7 & 14.0 & 0.0 \\
\hline & Human/Dog & 8.1 & 8.3 & \multirow[b]{2}{*}{0.0} \\
\hline & Island Fox & 13.7 & 14.0 & \\
\hline & $1900 \mathrm{~s}$ & 9.1 & 9.5 & \multirow[b]{2}{*}{0.0} \\
\hline & Late Holocene & 6.9 & 7.3 & \\
\hline Santa Catalina & Island Fox & 4.7 & 5.0 & \\
\hline \multirow{2}{*}{ San Clemente } & Human & 4.5 & 4.7 & \multirow{2}{*}{0.0} \\
\hline & Island Fox & 12.3 & 12.8 & \\
\hline
\end{tabular}

716 Bayesian Standard Ellipse Area in $\%^{2}$.

7172 Standard Ellipse Area corrected for small sample sizes.

$718{ }^{3}$ The overlap between two SEAc ellipses. 


\section{References}

Aguilar, A., Roemer, G., Debenham, S., Binns, M., Garcelon, D., Wayne, R.K., 2004. High MHC diversity maintained by balancing selection in an otherwise genetically monomorphic mammal. Proc. Natl. Acad. Sci. U. S. A. 101, 3490-3494. doi:10.1073/pnas.0306582101

Anderson, R.S., Starratt, S., Jass, R.M.B., Pinter, N., 2010. Fire and vegetation history on Santa Rosa Island, Channel Islands, and long-term environmental change in southern California. J. Quat. Sci. 25, 782-797. doi:10.1002/jqs.1358

Auman, H.J., Bond, A.L., Meathrel, C.E., Richardson, A.M.M., 2011. Urbanization of the Silver Gull: Evidence of Anthropogenic Feeding Regimes from Stable Isotope Analyses. Waterbirds 34, 70-76. doi:10.1675/063.034.0108

Axelsson, E., Ratnakumar, A., Arendt, M.-L., Maqbool, K., Webster, M.T., Perloski, M., Liberg, O., Arnemo, J.M., Hedhammar, A., Lindblad-Toh, K., 2013. The genomic signature of dog domestication reveals adaptation to a starch-rich diet. Nature. doi:10.1038/nature11837

Bartelle, B.G., Vellanoweth, R.L., Netherton, E.S., Poister, N.W., Kendig, W.E., Ainis, A.F., Glenn, R.J., Marty, J.V., Thomas-Barnett, L., Schwartz, S.J., 2010. Trauma and pathology of a buried dog from San Nicolas Island, California, U.S.A. J. Archaeol. Sci. 37, 2721-2734. doi:10.1016/j.jas.2010.06.008

Barton, L., Newsome, S.D., Chen, F.-H., Wang, H., Guilderson, T.P., Bettinger, R.L., 2009. Agricultural origins and the isotopic identity of domestication in northern China. Proc. Natl. Acad. Sci. 106, 5523-5528. doi:10.1073/pnas.0809960106

Beard, B., Johnson, C., 2000. Strontium isotope composition of skeletal material can determine the birth place and geographic mobility of humans and animals. J. Forensic Sci. 45, 1049-1061.

Bentzen, T.W., Shideler, R.T., O’Hara, T.M., 2014. Use of stable isotope analysis to identify food-conditioned grizzly bears on Alaska's North Slope. Ursus 25, 14-23. doi:10.2192/URSUS-D-13-00002.1

Cannon, A., Schwarcz, H.P., Knyf, M., 1999. Marine-based Subsistence Trends and the Stable Isotope Analysis of Dog Bones from Namu, British Columbia. J. Archaeol. Sci. 26, 399407. doi:10.1006/jasc.1998.0341

Collins, P.W., 1993. Taxonomic and Biogeographic Relationships of the Island Fox (Urocyon littoralis) and Gray Fox (U. cinereoargenteus) from Western North America, in: Third California Islands Symposium: Recent Advances in Research on the California Islands. Santa Barbara Museum of Natural History, Santa Barbara, pp. 351-390.

Collins, P.W., 1991a. Interaction between Island Foxes (Urocyon littoralis) and Indians on Islands off the Coast of Southern California: I. Morphological and Archaeological Evidence of Human Assisted Dispersal. J. Ethnobiol. 11, 51-81.

Collins, P.W., 1991b. Interaction Between Island Foxes (Urocyon littoralis) and Native Americans on Islands off the Coast of Southern California: II. Ethnographic, Archaeological, and Historical Evidence. J. Ethnobiol. 11, 205-229.

Coonan, T.J., 2015. Seventeenth annual meeting of the Island Fox Working Group (Summary Report). Ventura, California. 
Coonan, T.J., Bakker, V., Hudgens, B., Boser, C.L., Garcelon, D.K., Morrison, S.A., 2014. On the fast track to recovery: island foxes on the northern Channel Islands. Monogr. West. North Am. Nat. 7, 373-381.

Coonan, T.J., Schwemm, C.A., Garcelon, D.K., 2010. Decline and Recovery of the Island Fox: A Case Study for Population Recovery. Cambridge University Press.

Corry, P., McEachern, K., 2009. Patterns in post-grazing vegetation changes among species and environments, San Miguel and Santa Barbara Islands, in: Daimani, C.C., Garcelon, D.K. (Eds.), Proceedings of the Seventh California Islands Symposium. Institute of Wildlife Studies, Arcata, CA, pp. 201-214.

Cuarón, A.D., Martínez-Morales, M.A., Mcfadden, K.W., Valenzuela, D., Gompper, M.E., 2004. The status of dwarf carnivores on Cozumel Island, Mexico. Biodivers. Conserv. 13, 317 331. doi:10.1023/B:BIOC.0000006501.80472.cc

Cunningham, S.C., Kirkendall, L., Ballard, W., 2006. Gray fox and coyote abundance and diet responses after a wildfire in central Arizona. West. North Am. Nat. 66, 169-180.

Cypher, B.L., Madrid, A.Y., Van Horn Job, C.L., Kelly, E.C., Harrison, S.W.R., Westall, T.L., 2014. Multi-population comparison of resource exploitation by island foxes: Implications for conservation. Glob. Ecol. Conserv. 2, 255-266. doi:10.1016/j.gecco.2014.10.001

Erlandson, J.M., Braje, T.J., DeLong, R.L., Rick, T.C., 2014. Historical ecology and Pacific Coast pinnipeds. In, in: Kittinger, J.N., McClenahan, L., Gedan, K.B., Blight, L.K. (Eds.), Marine Historical Ecology in Conservation: Applying the Past to Manage the Future. University of California Press, Berkeley, pp. 39-62.

Erlandson, J.M., Rick, T.C., Braje, T.J., Casperson, M., Culleton, B., Fulfrost, B., Garcia, T., Guthrie, D.A., Jew, N., Kennett, D.J., Moss, M.L., Reeder, L., Skinner, C., Watts, J., Willis, L., 2011. Paleoindian Seafaring, Maritime Technologies, and Coastal Foraging on California's Channel Islands. Science 331, 1181 -1185. doi:10.1126/science. 1201477

Erlandson, J.M., Rick, T.C., Peterson, C., 2005. A geoarchaeological chronology of Holocene dune building on San Miguel Island, California. The Holocene 15, 1227-1235. doi:10.1191/0959683605hl893rp

Francey, R.J., Allison, C.E., Etheridge, D.M., Trudinger, C.M., Enting, I.G., Leuenberger, M., Langenfelds, R.L., Michel, E., Steele, L.P., 1999. A 1000-year high precision record of $\delta 13 \mathrm{C}$ in atmospheric CO2. Tellus B 51, 170-193. doi:10.1034/j.1600-0889.1999.t01-100005.x

Fritzell, E., 1988. Wild Furbearer Management and Conservation in North America. Ontario Ministry of Natural Resources.

Fuller, B. t., Fuller, J. 1., Harris, D. a., Hedges, R. e. m., 2006. Detection of breastfeeding and weaning in modern human infants with carbon and nitrogen stable isotope ratios. Am. J. Phys. Anthropol. 129, 279-293. doi:10.1002/ajpa.20249

Funk, W.C., Lovich, R.E., Hohenlohe, P.A., Hofman, C.A., Morrison, S.A., Sillett, T.S., Ghalambor, C.K., Maldonado, J.E., Rick, T.C., Day, M.D., Polato, N.R., Fitzpatrick, S.W., Coonan, T.J., Crooks, K.R., Dillon, A., Garcelon, D.K., King, J.L., Boser, C.L., Gould, N., Andelt, W.F., 2016. Adaptive divergence despite strong genetic drift: genomic analysis of the evolutionary mechanisms causing genetic differentiation in the island fox (Urocyon littoralis). Mol. Ecol. 25, 2176-2194. doi:10.1111/mec.13605

Gilbert, D.A., Lehman, N., O’Brien, S.J., Wayne, R.K., 1990. Genetic fingerprinting reflects population differentiation in the California Channel Island fox. Nature 344, 764-767. doi: $10.1038 / 344764 \mathrm{a} 0$ 
Gill, K.M., 2014. Seasons of Change: Using Seasonal Morphological Changes in Brodiaea Corms to Determine Season of Harvest from Archaeobotanical Remains. Am. Antiq. 79, 638-654. doi:10.7183/0002-7316.79.4.638

Goldberg, C.F., 1993. The Application of Stable Carbon and Nitrogen Isotope Analysis to Human Dietary Reconstruction in Prehistoric Southern California (PhD Dissertation). University of California, Los Angeles, Los Angeles, California.

Gompper, M.E., Petrites, A.E., Lyman, R.L., 2006. Cozumel Island fox (Urocyon sp.) dwarfism and possible divergence history based on subfossil bones. J. Zool. 270, 72-77. doi:10.1111/j.1469-7998.2006.00119.x

Grayson, D.K., 2001. The archaeological record of human impacts on animal populations. J. World Prehistory 15, 1-68.

Guiry, E.J., 2012. Dogs as Analogs in Stable Isotope-Based Human Paleodietary Reconstructions: A Review and Considerations for Future Use. J. Archaeol. Method Theory 19, 351-376. doi:10.1007/s10816-011-9118-z

Guthrie, D.A., 1993. New Information on the Prehistoric Fauna of San Miguel Island: Presented at the Third Channel Islands Symposium, Santa Barbara, pp. 405-416.

Hale, A., Salls, R., 2000. The Canine Ceremony: Dog and Fox Burials of San Clemente Island. Pac. Coast Archaeol. Soc. Q. 36, 70-90.

Heiss, R.S., Clark, A.B., McGowan, K.J., 2009. Growth and nutritional state of American Crow nestlings vary between urban and rural habitats. Ecol. Appl. Publ. Ecol. Soc. Am. 19, 829-839.

Hobson, K.A., Clark, R.G., 1992. Assessing Avian Diets Using Stable Isotopes I: Turnover of 13C in Tissues. The Condor 94, 181-188. doi:10.2307/1368807

Hofman, C.A., Rick, T.C., Fleischer, R.C., Maldonado, J.E., 2015a. Conservation archaeogenomics: ancient DNA and biodiversity in the Anthropocene. Trends Ecol. Evol. 30, 540-549. doi:10.1016/j.tree.2015.06.008

Hofman, C.A., Rick, T.C., Hawkins, M.T.R., Funk, W.C., Ralls, K., Boser, C.L., Collins, P.W., Coonan, T., King, J.L., Morrison, S.A., Newsome, S.D., Sillett, T.S., Fleischer, R.C., Maldonado, J.E., 2015b. Mitochondrial Genomes Suggest Rapid Evolution of Dwarf California Channel Islands Foxes (Urocyon littoralis). PLoS ONE 10, e0118240. doi:10.1371/journal.pone.0118240

Hu, Y., Luan, F., Wang, S., Wang, C., Richards, M.P., 2008. Preliminary attempt to distinguish the domesticated pigs from wild boars by the methods of carbon and nitrogen stable isotope analysis. Sci. China Ser. Earth Sci. 52, 85-92. doi:10.1007/s11430-008-0151-z

Jackson, A.L., Inger, R., Parnell, A.C., Bearhop, S., 2011. Comparing isotopic niche widths among and within communities: SIBER - Stable Isotope Bayesian Ellipses in R. J. Anim. Ecol. 80, 595-602. doi:10.1111/j.1365-2656.2011.01806.x

Jackson, A.P. and A., 2010. siar: Stable Isotope Analysis in R.

Jackson, R.H., Castillo, E., 1996. Indians, Franciscans, and Spanish Colonization: The Impact of the Mission System on California Indians. UNM Press.

Jazwa, C., Kennett, D., Hanson, D., 2012. Late Holocene Subsistence Change and Marine Productivity on Western Santa Rosa Island, Alta California. Calif. Archaeol. 4, 69-98. doi:10.1179/cal.2012.4.1.69

Jenkins, S.G., Partridge, S.T., Stephenson, T.R., Farley, S.D., Robbins, C.T., 2001. Nitrogen and carbon isotope fractionation between mothers, neonates, and nursing offspring. Oecologia 129, 336-341. doi:10.1007/s004420100755 
Jew, N.P., Rick, T.C., Sullivan, K.J., Erlandson, J.M., 2015. Lithic Technologies from Late Holocene Anacapa Island, California: Local Reliance on Anayapax Chert. J. Calif. Gt. Basin Anthropol.

Johnson, D.J., 1983. The California Continental Borderland: Land bridges, Watergaps, and Biotic Dispersals, in: Quaternary Coastlines and Marine Archaeology: Towards the Prehistory of Land Bridges and Continental Shelves. Academic Press, London, pp. 481527.

Johnson, D.L., 1980. Episodic vegetation stripping, soil erosion, and landscape modification in prehistoric and recent historic time, San Miguel Island, California, in: The California Islands: Proceedings of a Multidisciplinary Symposium. Santa Barbara Museum of Natural History, Santa Barbara, CA, pp. 103-122.

Johnson, D.L., 1975. New Evidence on the Origin of the Fox, Urocyon littoralis clementae, and Feral Goats on San Clemente Island, California. J. Mammal. 56, 925-928.

Kennett, D.J., 2005. The Island Chumash: Behavioral Ecology of a Maritime Society. University of California Press.

Kristan, W.B., Boarman, W.I., Crayon, J.J., 2004. Diet composition of common ravens across the urban-wildland interface of the West Mojave Desert. Wildl. Soc. Bull. 32, 244-253. doi:10.2193/0091-7648(2004)32[244:DCOCRA]2.0.CO;2

Laughrin, L., 1977. The Island fox: a field study of its behavior and ecology (Dissertation). University of California, Santa Barbara.

Lorenzen, E.D., Nogues-Bravo, D., Orlando, L., Weinstock, J., Binladen, J., Marske, K.A., Ugan, A., Borregaard, M.K., Gilbert, M.T.P., Nielsen, R., Ho, S.Y.W., Goebel, T., Graf, K.E., Byers, D., Stenderup, J.T., Rasmussen, M., Campos, P.F., Leonard, J.A., Koepfli, K.-P., Froese, D., Zazula, G., Stafford, T.W., Aaris-Sorensen, K., Batra, P., Haywood, A.M., Singarayer, J.S., Valdes, P.J., Boeskorov, G., Burns, J.A., Davydov, S.P., Haile, J., Jenkins, D.L., Kosintsev, P., Kuznetsova, T., Lai, X., Martin, L.D., McDonald, H.G., Mol, D., Meldgaard, M., Munch, K., Stephan, E., Sablin, M., Sommer, R.S., Sipko, T., Scott, E., Suchard, M.A., Tikhonov, A., Willerslev, R., Wayne, R.K., Cooper, A., Hofreiter, M., Sher, A., Shapiro, B., Rahbek, C., Willerslev, E., 2011. Species-specific responses of Late Quaternary megafauna to climate and humans. Nature 479, 359-364. doi:10.1038/nature10574

Makarewicz, C., Tuross, N., 2012. Finding Fodder and Tracking Transhumance: Isotopic Detection of Goat Domestication Processes in the Near East. Curr. Anthropol. 53, 495505. doi:10.1086/665829

McEachern, K., Atwater, T., Collins, P., Faulkner, K.R., Richards, D.V., 2015. Managed Island Ecosystems, in: Mooney, H., Zavaleta, E. (Eds.), Ecosystems of California. University of California Press.

Merkle, J.A., Derbridge, J.J., Krausman, P.R., 2011. Using stable isotope analysis to quantify anthropogenic foraging in black bears. Hum.-Wildl. Interact. 5, 159-167.

Moore, C.M., Collins, P.W., 1995. Urocyon littoralis. Mamm. Species.

Muhs, D.R., Simmons, K.R., Schumann, R.R., Groves, L.T., DeVogel, S.B., Minor, S.A., Laurel, D., 2014. Coastal tectonics on the eastern margin of the Pacific Rim: late Quaternary sealevel history and uplift rates, Channel Islands National Park, California, USA. Quat. Sci. Rev. 105, 209-238. doi:10.1016/j.quascirev.2014.09.017

Muhs, D.R., Simmons, K.R., Schumann, R.R., Groves, L.T., Mitrovica, J.X., Laurel, D., 2012. Sea-level history during the Last Interglacial complex on San Nicolas Island, California: 
implications for glacial isostatic adjustment processes, paleozoogeography and tectonics. Quat. Sci. Rev. 37, 1-25. doi:10.1016/j.quascirev.2012.01.010

Newsome, S.D., Collins, P.W., Sharpe, P., 2015. Foraging ecology of a reintroduced population of breeding Bald Eagles on the Channel Islands, California, USA, inferred from prey remains and stable isotope analysis. The Condor 117, 396-413. doi:10.1650/CONDOR14-213.1

Newsome, S.D., Koch, P.L., Etnier, M.A., Aurioles-Gamboa, D., 2006. Using Carbon and Nitrogen Isotope Values to Investigate Maternal Strategies in Northeast Pacific Otariids. Mar. Mammal Sci. 22, 556-572. doi:10.1111/j.1748-7692.2006.00043.x

Newsome, S.D., Ralls, K., Job, C.V.H., Fogel, M.L., Cypher, B.L., 2010. Stable isotopes evaluate exploitation of anthropogenic foods by the endangered San Joaquin kit fox (Vulpes macrotis mutica). J. Mammal. 91, 1313-1321. doi:10.1644/09-MAMM-A-362.1

Orr, P.C., 1968. Prehistory of Santa Rosa Island. Santa Barbara Museum of Natural History, Santa Barbara, CA.

Parnell, A.J. and A., 2011. SIBER: Stable Isotope Bayesian Ellipses in R.

Pearce, A.I., Richards, R.G., Milz, S., Schneider, E., Pearce, S.G., others, 2007. Animal models for implant biomaterial research in bone: a review. Eur Cell Mater 13, 1-10.

Powers, R.., 2009. Social behavior measured by home range overlap in island foxes (Urocyon littoralis dickey) (Masters Thesis). San Francisco State University, San Francisco, CA.

Raab, Cassidy, 2009. California Maritime Archaeology: A San Clemente Island Perspective. Rowman Altamira.

Ramsey, C.B., 2013. OxCal 4.2.

Ramsey, C.B., 2009. Bayesian Analysis of Radiocarbon Dates. Radiocarbon 51, 337-360. doi:10.2458/azu_js_rc.51.3494

Ramsey, C.B., Gigham, T., Leach, P., 2007a. Towards high-precision AMS; progress and limitations. Radiocarbon 46, 17-24. doi:10.2458/azu_js_rc.46.4239

Ramsey, C.B., Higham, T., Bowles, A., Hedges, R., 2007b. Improvements to the pretreatment of bone at Oxford. Radiocarbon 46, 155-163. doi:10.2458/azu_js_rc.46.4256

R Core Team, 2015. R. R Foundation for Statistical Computing, Vienna, Austria.

Reeder, L.A., Rick, T.C., 2009. New Perspectives on the Archaeology of Anacapa Island, California: Preliminary Research at ANI-2, in: Proceedings of the Society for California Archaeology. p. 119.

Reeder-Myers, L., Erlandson, J.M., Muhs, D.R., Rick, T.C., 2015. Sea level, paleogeography, and archaeology on California's Northern Channel Islands. Quat. Res. doi:10.1016/j.yqres.2015.01.002

Reimer, P.J., Bard, E., Bayliss, A., Beck, J.W., Blackwell, P.G., Bronk Ramsey, C., Buck, C.E., Cheng, H., Edwards, R.L., Friedrich, M., Grootes, P.M., Guilderson, T.P., Haflidason, H., Hajdas, I., Hatte, C., Heaton, T.J., Hoffmann, D.L., Hogg, A.G., Hughen, K.A., Kaiser, K.F., Kromer, B., Manning, S.W., Niu, M., Reimer, R.W., Richards, D.A., Scott, E.M., Southon, J.R., Staff, R.A., Turney, C.S.M., van der Plicht, J., 2013. IntCal13 and Marine13 radiocarbon age calibration curves 0-50,000 years cal BP.

Resnick, J.R., Andelt, W.F., 2012. Reproductive ecology and characteristics of denning sites San Clemente Island Fox. Southwest. Nat. 57, 170-175.

Rick, T.C., 2013. Hunter-Gatherers, Endemic Island Mammals, and the Historical Ecology of California's Channel Islands, in: Thompson, V.D., Waggoner Jr., J.C. (Eds.), The 
Archaeology and Historical Ecology of Small Scale Economies. University Press of Florida, pp. 41-64.

Rick, T.C., Culleton, B.J., Smith, C.B., Johnson, J.R., Kennett, D.J., 2011. Stable isotope analysis of dog, fox, and human diets at a Late Holocene Chumash village (CA-SRI-2) on Santa Rosa Island, California. J. Archaeol. Sci. 38, 1385-1393. doi:10.1016/j.jas.2011.02.008

Rick, T.C., Erlandson, J., 2008. Human impacts on ancient marine ecosystems: a global perspective. University of California Press.

Rick, T.C., Erlandson, J.M., Jew, N.P., Reeder-Myers, L.A., 2013. Archaeological survey, paleogeography, and the search for Late Pleistocene Paleocoastal peoples of Santa Rosa Island, California. J. Field Archaeol. 38, 324-331.

Rick, T.C., Erlandson, J.M., Vellanoweth, R., Braje, T.J., Guthrie, D.A., Stafford Jr., T.W., 2009. Origins and Antiquity of the Island Fox (Urocyon littoralis) on California's Channel Islands. Quat. Res. 71, 93-98.

Rick, T.C., Erlandson, J.M., Vellanoweth, R.L., Braje, T.J., 2005. From Pleistocene Mariners to Complex Hunter-Gatherers: The Archaeology of the California Channel Islands. J. World Prehistory 19, 169-228. doi:10.1007/s10963-006-9004-x

Rick, T.C., Sillett, T.S., Ghalambor, C.K., Hofman, C.A., Ralls, K., Anderson, R.S., Boser, C.L., Braje, T.J., Cayan, D.R., Chesser, R.T., Collins, P.W., Erlandson, J.M., Faulkner, K.R., Fleischer, R., Funk, W.C., Galipeau, R., Huston, A., King, J., Laughrin, L., Maldonado, J., McEachern, K., Muhs, D.R., Newsome, S.D., Reeder-Myers, L., Still, C., Morrison, S.A., 2014. Ecological Change on California's Channel Islands from the Pleistocene to the Anthropocene. BioScience 64, 680-692. doi:10.1093/biosci/biu094

Rick, T.C., Walker, P.L., Willis, L.M., Noah, A.C., Erlandson, J.M., Vellanoweth, R., Braje, T.J., Kennett, D.J., 2008. Dogs, Humans and Island Ecosystems: The Distribution, Antiquity, and Ecology of the Domestic Dogs (Canis familiaris) on California's Channel Islands, USA. The Holocene 18, 1077-1087.

Robinson, J.A., Vecchyo, D.O.-D., Fan, Z., Kim, B.Y., vonHoldt, B.M., Marsden, C.D., Lohmueller, K.E., Wayne, R.K., 2016. Genomic Flatlining in the Endangered Island Fox. Curr. Biol. 26, 1183-1189. doi:10.1016/j.cub.2016.02.062

Roemer, G.W., Donlan, C.J., Courchamp, F., 2002. Golden eagles, feral pigs, and insular carnivores: how exotic species turn native predators into prey. Proc. Natl. Acad. Sci. 99, 791-796.

Shelley, S.D., 2001. Archaeological Evidence of the Island Fox (Urocyon littoralis) on California's Channel Islands (No. Statistical Research Technical Report 98-12). Prepared for Naval Air Weapons Station, Point Mugu.

Smith, C.M., 2013. Reconstructing the Diet of Domestic Dogs (Canis familiaris) and Island Foxes (Urocyon littoralis) Excavated from San Nicolas Island, California: the Application of Stable Carbon and Nitrogen Isotope Analysis of Bone Collagen and Apatite. (Masters Thesis). California State University, Los Angeles, Los Angeles, California.

Storey, A.A., Clarke, A.C., Ladefoged, T., Robins, J., Matisoo-Smith, E., 2013. DNA and Pacific Commensal Models: Applications, Construction, Limitations, and Future Prospects. J. Isl. Coast. Archaeol. 8, 37-65. doi:10.1080/15564894.2012.761299 
1004

1005

1006

1007

1008

1009

1010

1011

1012

1013

1014

1015

1016

1017

1018

1019

1020

1021

1022

1023

1024

1025

1026

1027

1028

1029

1030

1031

1032

1033

1034
Sugiyama, N., Somerville, A.D., Schoeninger, M.J., 2015. Stable Isotopes and Zooarchaeology at Teotihuacan, Mexico Reveal Earliest Evidence of Wild Carnivore Management in Mesoamerica. PLoS ONE 10, e0135635. doi:10.1371/journal.pone.0135635

Tankersley, K.B., Koster, J.M., 2009. Sources of stable isotope variation in archaeological dog remains. North Am. Archaeol. 30, 361-375.

Tieszen, L.L., Boutton, T.W., 1989. Stable Carbon Isotopes in Terrestrial Ecosystem Research, in: Rundel, P.W., Ehleringer, J.R., Nagy, K.A. (Eds.), Stable Isotopes in Ecological Research, Ecological Studies. Springer New York, pp. 167-195.

Tieszen, L.L., Boutton, T.W., Tesdahl, K.G., Slade, N.A., 1983. Fractionation and turnover of stable carbon isotopes in animal tissues: Implications for $813 \mathrm{C}$ analysis of diet. Oecologia 57, 32-37. doi:10.1007/BF00379558

Vellanoweth, R.L., 1998. Earliest Island Fox Remains on the Southern Channel Islands: Evidence from San Nicolas Island, California. J. Calif. Gt. Basin Anthropol. 20, 100-108.

Vellanoweth, R.L., Bartelle, B.G., Anis, A.F., Cannon, A., Schwartz, S.J., 2008. A double dog burial from San Nicolas Island, California, USA: osteology, context, and significance. J. Archaeol. Sci. 35, 3111-3123.

Wastlhuber, J., 1991. History of domestic cats and cat breeds, in: Pedersen, N. (Ed.), Feline Husbandry. American Veterinary Publications, Inc, Goleta, CA, pp. 1-59.

Wayne, R.K., George, S.B., Gilbert, D., Collins, P.W., Kovach, S.D., Girman, D., Lehman, N., 1991. A Morpological and Genetic Study of the of Island Fox, Urocyon littoralis. Evolution 45, 1849-1868.

Wenner, A.M., Johnson, D.J., 1980. Land vertebrates on the islands: sweepstakes or landbridges?, in: The California Islands: Proceedings of a Multidisciplinary Symposium. Santa Barbara Museum of Natural History, Santa Barbara, pp. 497-530.

West, C.F., France, C.A., 2015. Human and Canid Dietary Relationships: Comparative Stable Isotope Analysis From the Kodiak Archipelago, Alaska. J. Ethnobiol. 35, 519-535. doi:10.2993/etbi-35-03-519-535.1

White, C.D., Pohl, M.E.D., Schwarcz, H.P., Longstaffe, F.J., 2001. Isotopic Evidence for Maya Patterns of Deer and Dog Use at Preclassic Colha. J. Archaeol. Sci. 28, 89-107. doi:10.1006/jasc. 1999.0560

Wiley, A.E., Ostrom, P.H., Welch, A.J., Fleischer, R.C., Gandhi, H., Southon, J.R., Stafford, T.W., Penniman, J.F., Hu, D., Duvall, F.P., James, H.F., 2013. Millennial-scale isotope records from a wide-ranging predator show evidence of recent human impact to oceanic food webs. Proc. Natl. Acad. Sci. 110, 8972-8977. doi:10.1073/pnas.1300213110

Zeder, M.A., 2015. Core questions in domestication research. Proc. Natl. Acad. Sci. 201501711. doi:10.1073/pnas.1501711112

Zeder, M.A., 2006. Archaeological Approaches to Documenting Animal Domestication, in: Zeder, M.A., Bradley, D.G., Emshwiller, E., Smith, B.D. (Eds.), Documenting Domestication: New Genetic and Archaeological Paradigms. University of California Press.

Zeder, M.A., Emshwiller, E., Smith, B.D., Bradley, D.G., 2006. Documenting domestication: the intersection of genetics and archaeology. Trends Genet. 22, 139-155. doi:10.1016/j.tig.2006.01.007 

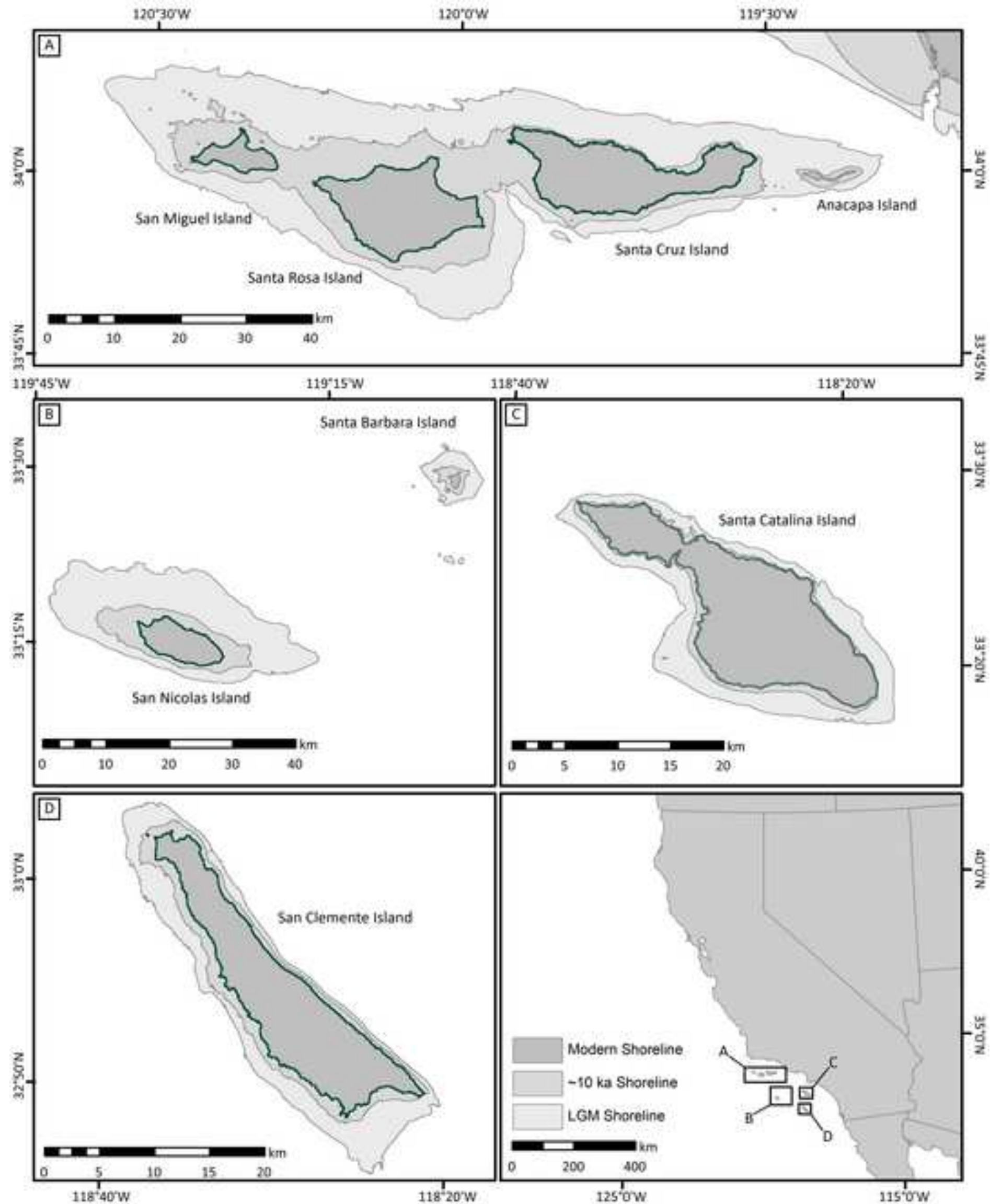
Figure 2
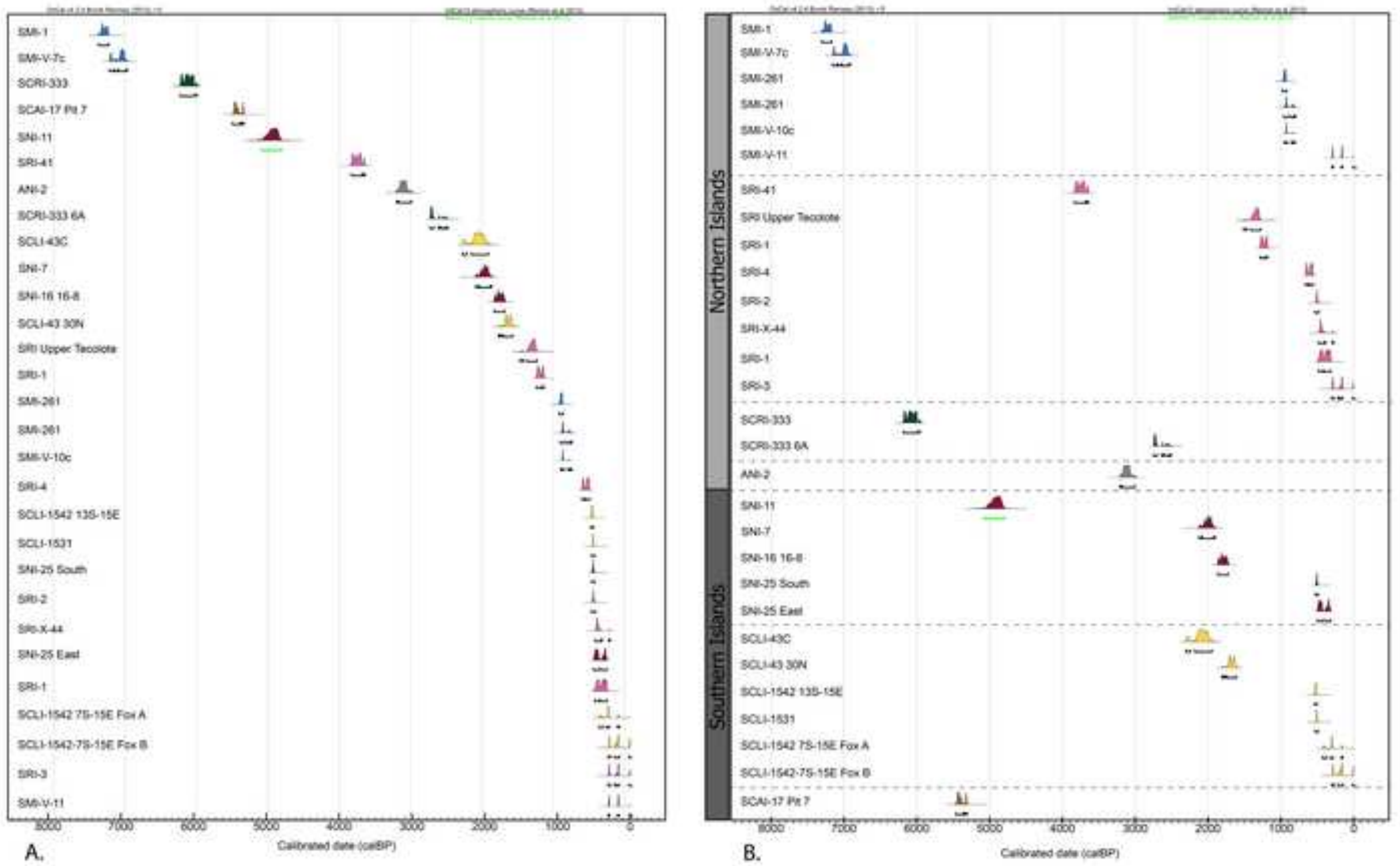

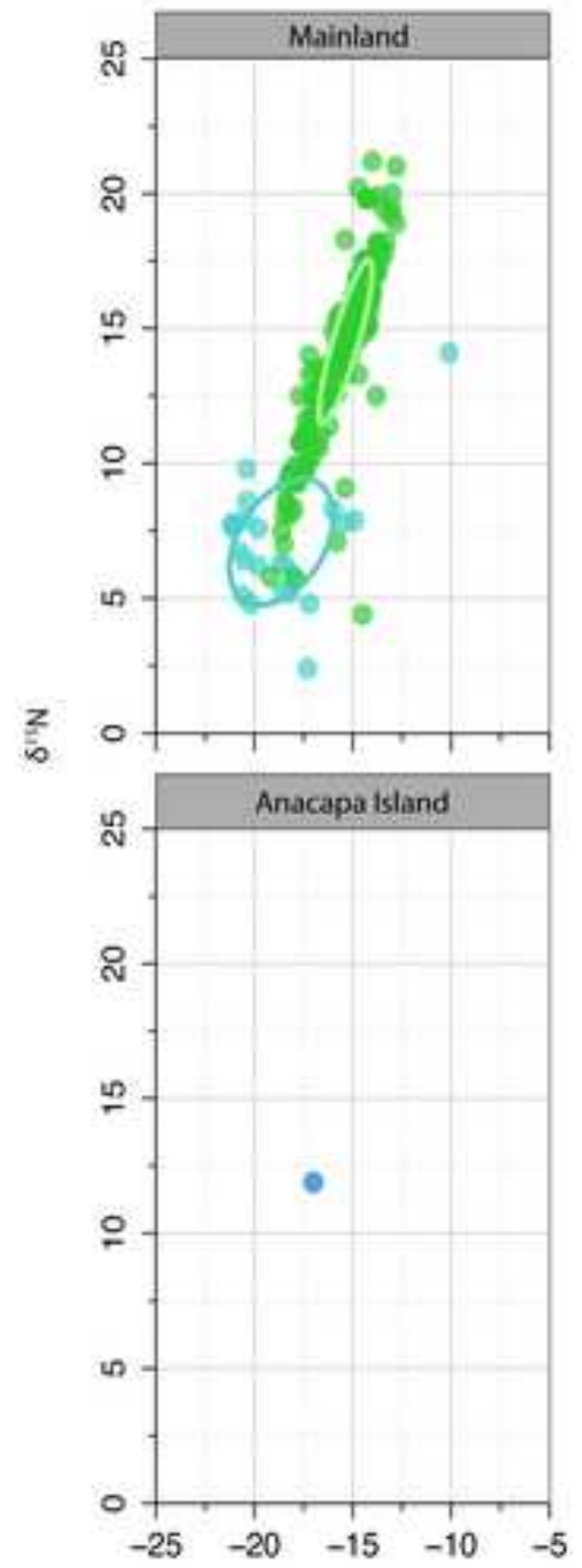
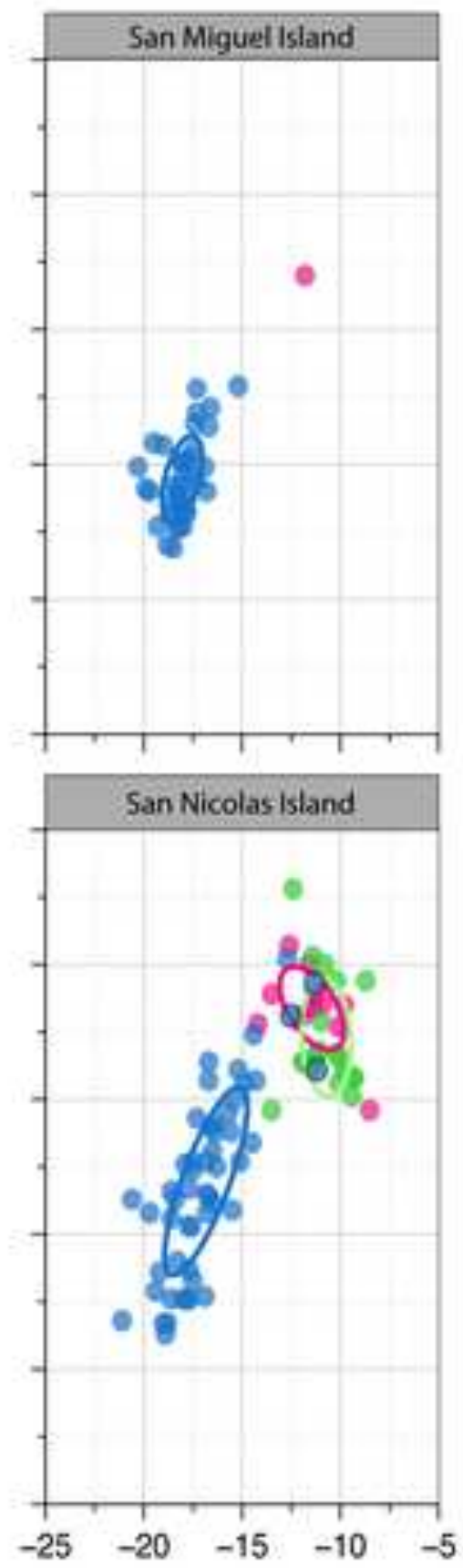
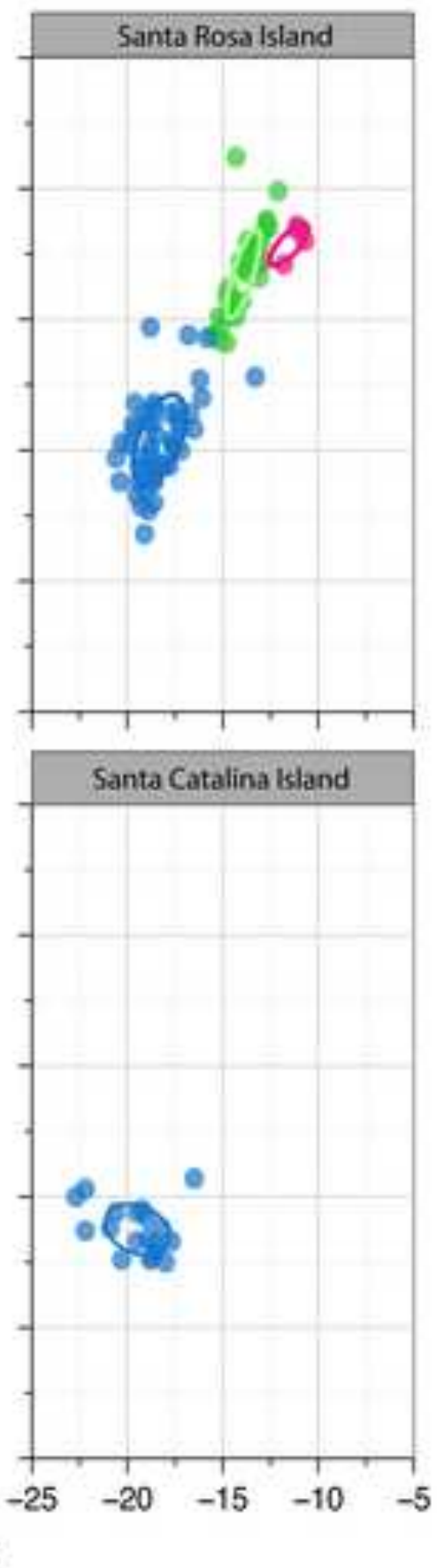

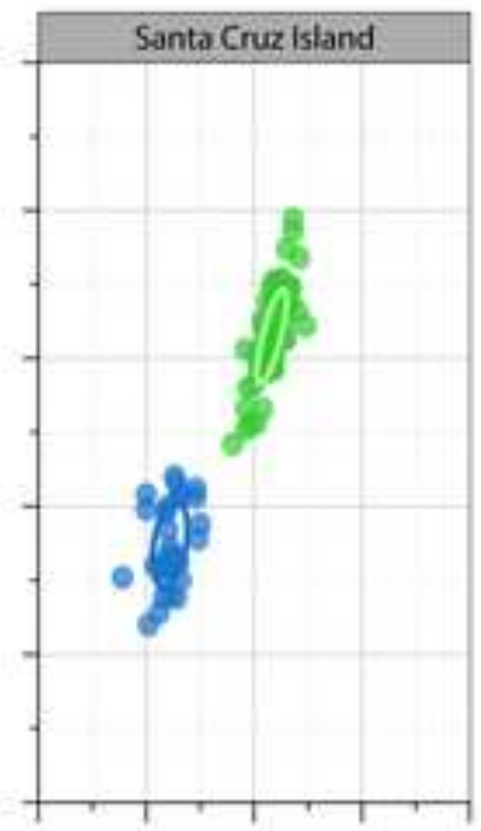

Species

- $\mathrm{Dog}$ -1il-Gray Fox

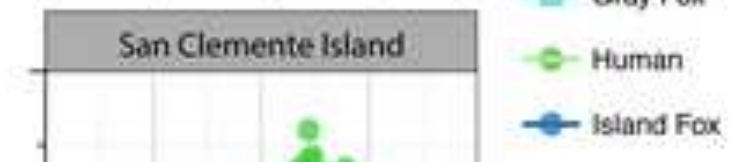

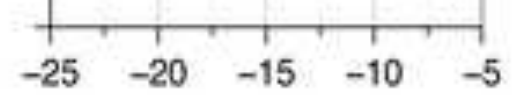


Figure 4
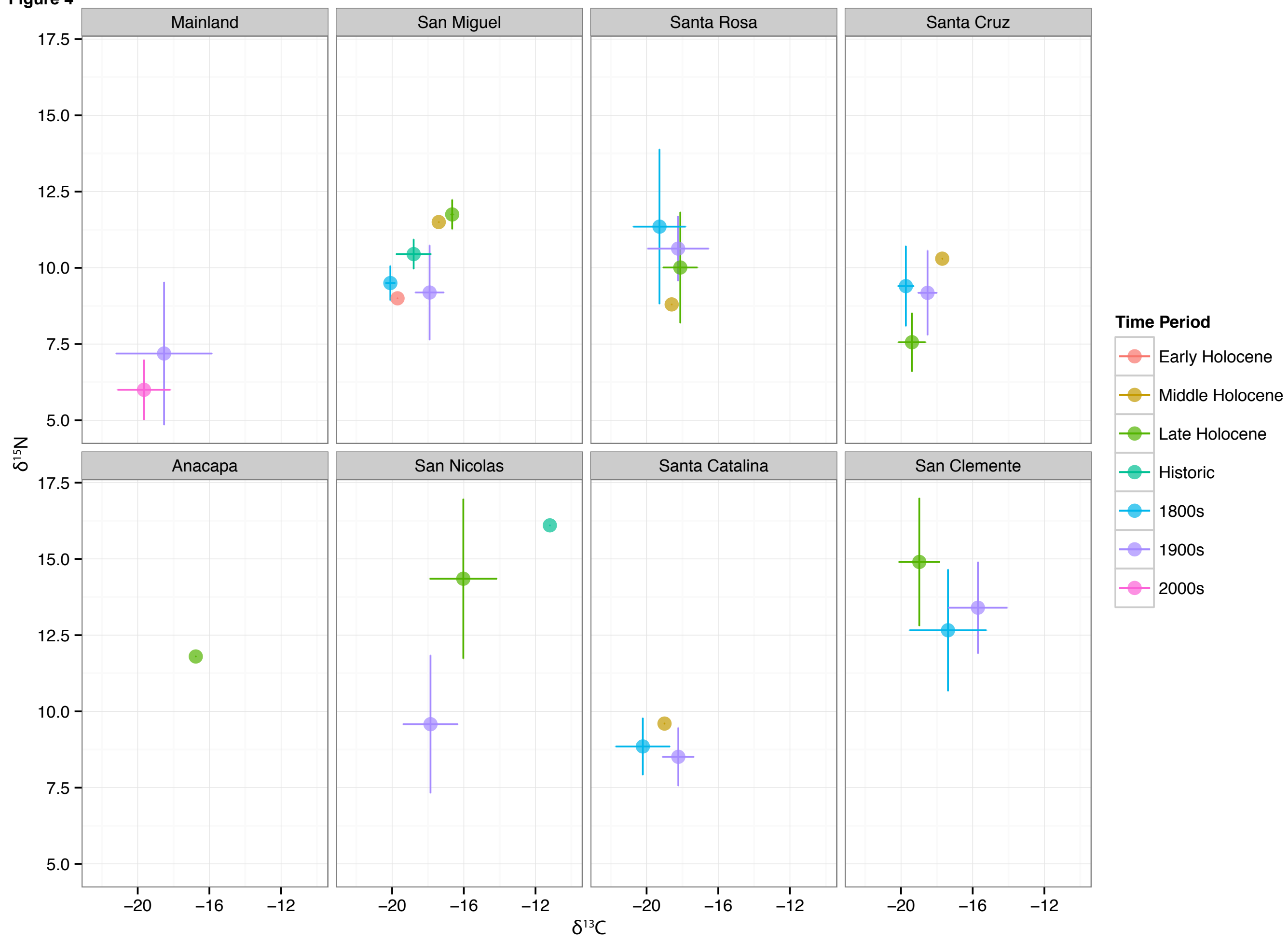

Time Period

arly Holocene

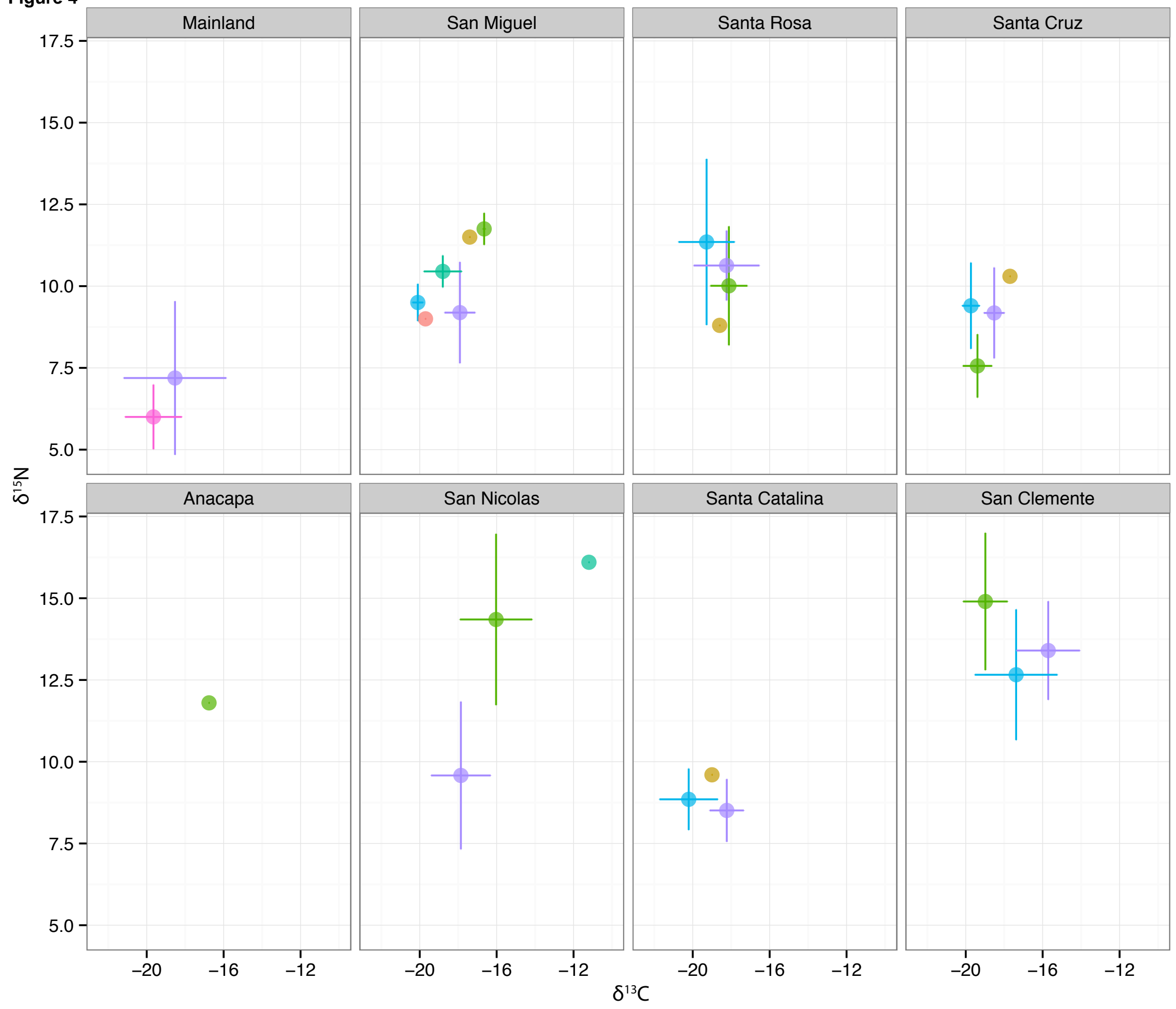




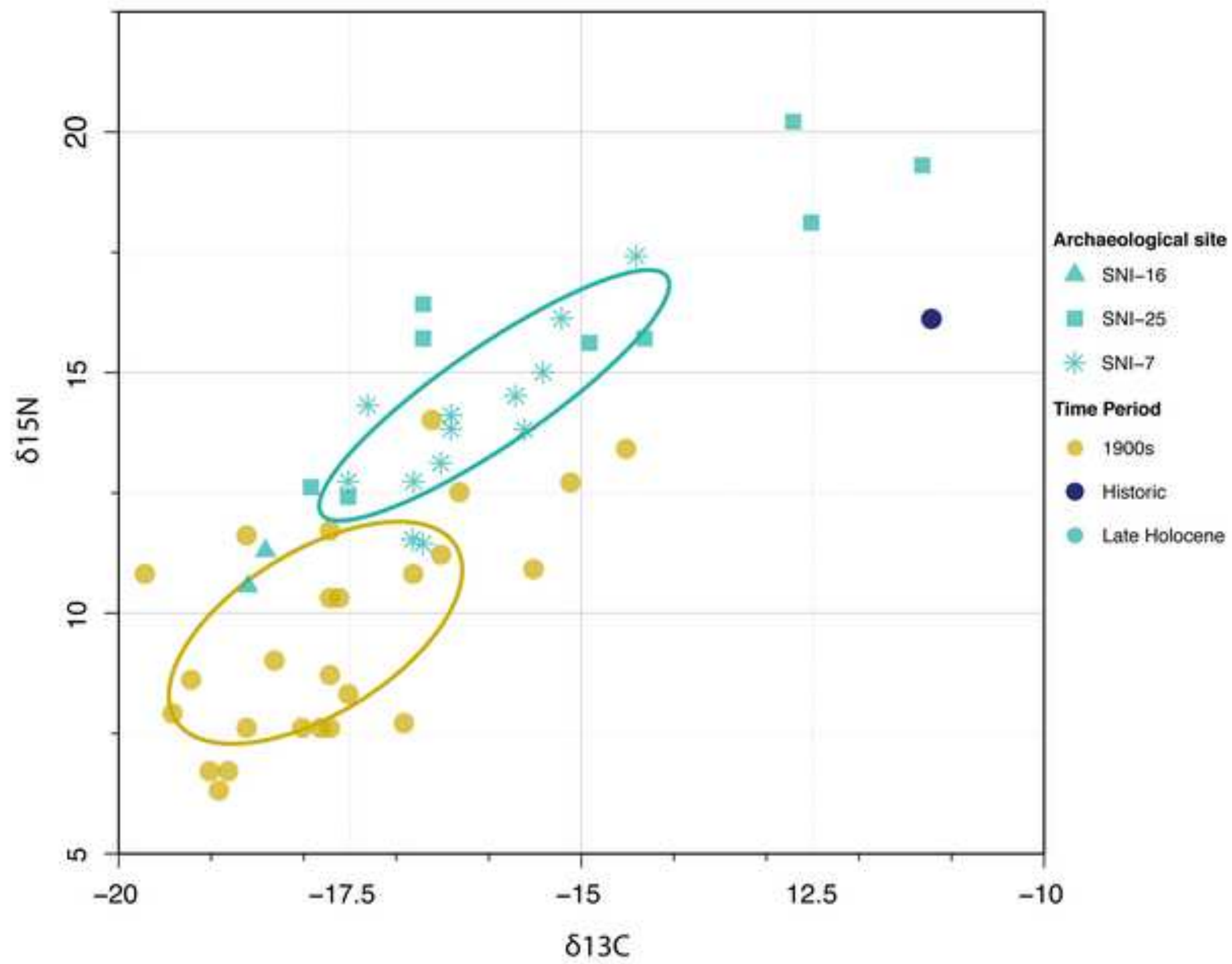

